Article

\title{
A Heuristic Rule-Based Passive Design Decision Model for Reducing Heating Energy Consumption of Korean Apartment Buildings
}

\section{Dongjun Suh ${ }^{1}$ and Seongju Chang ${ }^{2, *}$}

1 KAIST Institute for Information Technology Convergence, Korea Advanced Institute of Science and Technology (KAIST), Daejeon 305-701, Korea; E-Mail: djsuh@kaist.ac.kr

2 Department of Civil and Environmental Engineering, Korea Advanced Institute of Science and Technology (KAIST), Daejeon 305-701, Korea

* Author to whom correspondence should be addressed; E-Mail: schang@kaist.ac.kr; Tel.: +82-42-350-3627; Fax: +82-42-350-4540.

External Editor: Stephen Treado

Received: 3 July 2014; in revised form: 8 August 2014 / Accepted: 16 October 2014 /

Published: 29 October 2014

\begin{abstract}
This research presents an evaluative energy model for estimating the energy efficiency of the design choices of architects and engineers in the early design phase. We analyze the effects of various parameters with different characteristics in various combinations for building energy consumption. With this analysis, we build a database that identifies a set of heuristic rules for energy-efficient building design to facilitate the design of sustainable apartment housing. Perturbation studies are based on a sensitivity analysis used to identify the thermal influence of the input design parameters on various simulation outputs and compare the results to a reference case. Energy sensitivity weight factors are obtained from an extensive sensitivity study using building energy simulations. The results of the energy sensitivity study summarized in a set of heuristic rules for evaluating architectural features are estimated through case studies of Korean apartment buildings. This study offers valuable guidelines for developing energy-efficient residential housing in Korea and will help architects in considering appropriate design schemes and provide a ready reference to generalized test cases for both architects and engineers so that they can zero in on a set of effective design solutions.
\end{abstract}


Keywords: energy consumption model; heuristic rules; sensitivity analysis; energy-efficient buildings; Korean apartment buildings

\section{Introduction}

To reduce greenhouse gas emissions, various regulations and policies have been enacted for energy reduction in the building sector. The building sector comprises more than 40 percent of the total energy consumption in the world and occupies the highest portion of the total energy load in Korea [1,2]. Building energy accounts for a 30\% share of Korea's total annual energy consumption, and residential buildings account for nearly $60 \%$ of Korea's total building energy consumption [2-4].

As the Korean government has pursued reducing residential energy use [5-7], many researchers have studied and derived residential energy consumption models to construct energy efficient apartment housings in Korea. Most of the studies related to energy consumption in Korean housing focus on energy consumption patterns with respect to identifying each parameter's potential impact on energy performance.

To reduce building energy use, it is essential to optimize building design for energy efficiency at the early design phase so as to have the greatest impact on a building's thermal performance. Decisions made in the early design process, such as selection of a building's architectural components, form, and orientation, can remarkably decrease or increase a building's energy performance. Therefore, it is necessary to provide designers and architects with design decision support models to assist them in making energy efficient design decisions in the early design phase.

This study offers a simulated energy load profile and associated estimation model by iterating individual design parameters while keeping other parameters constant to establish a database that informs a set of heuristic rules for energy effective green home design.

The problem of obtaining optimal goals related to features representing a large number of variables and non-linear objective functions is known as an NP-hard problem. Deriving optimal combinations of architectural components while considering energy efficiency and cost is a puzzle that cannot be solved effectively using traditional optimization techniques. A heuristic method can be one of the most effective solutions. Heuristic refers to experience-based techniques for problem solving, learning, and discovery that offer a solution that is not guaranteed to be optimal but may be an efficient solution. Where an exhaustive search is impractical, heuristic methods can speed up the process of finding a satisfactory solution by mental shortcuts to ease the cognitive load of decision-making.

Heuristic methodology can also be used for deriving an optimized design solution considering energy consumption or cost reduction in the field of building energy. By establishing energy sensitive heuristic rules, architects and designers can determine the best alternative that will minimize the energy load. To do this, it is necessary to evaluate the energy effects of each architectural component by performing a sensitivity analysis of the parameters influencing energy consumption in apartment buildings.

According to previous studies [8,9], the sensitivity method evaluates the relationship between variations in output parameters and is used to solve optimization problems with numerous combination tests. To investigate a given feature as the subject of analysis in a complex model, the target factor must be iteratively changed and evaluated while other parameters remain fixed. The sensitivity method is 
often utilized in the fields of mathematics and control engineering, as in [10]. In economics, the concept of elasticity is used to estimate the sensitivity and responsiveness of a system [10].

Many studies using sensitivity analysis have been conducted to determine various design parameters that affect building energy consumption. Lam et al. [10] examined the sensitivity of energy performance of office buildings in Hong Kong. They analyzed important input design factors from the perspective of annual building energy consumption. Tavares et al. [11] investigated an intelligent design using sensitivity analysis to make a sustainable building in a town in the region of Portugal. Several options for constructive parameters have been explored for energy efficient building design. Westphal et al. [12] employed a sensitivity method for calibration of building simulation models by defining the factors that mostly influence the main electric end uses of a building. Sensitivity analysis has been used to derive the estimated cooling and heating loads to examine more precise values for those inputs that have a greater influence on the total thermal load.

A heuristic methodology based on sensitivity analysis is useful for evaluating the thermal performance of a building and identifying the level of uncertainty in building energy simulation results. This approach has a limitation in solving a non-linear problem in a building thermal environment, the sensitivity analysis can provide appropriate information for determining the best alternative for a given situation [10-13].

\section{Research Methodology}

This study focuses on discovering the effect of various parameters with different characteristics in various combinations. Input parameters are analyzed in terms of thermal performance of buildings that will inform a set of heuristic rules for energy-efficient building design.

Generally, cooling systems receive little consideration in the design phase in Korean climatic environment because the yearly cooling period is shorter than the heating period and because Koreans generally prefer floor heating systems. Therefore, we explore heating energy usage in Korean apartment buildings by utilizing a building energy simulation.

First, we conducted an extensive background study to choose proper parameters that have a potential impact on energy performance in Korean apartment buildings. In addition, the various research papers, as well as guidelines such as domestic regulation and policy for the Korean environment, are intensively analyzed to reflect the energy characteristics of apartment buildings in Korea.

Second, we performed building energy simulation tests with selected parameters and information and derived passive design heuristic rules in accordance with thermal performance.

Third, energy-sensitive factors with validation processes were performed to deduce influence factors and create an energy sensitive performance model from a simulated energy load profile. We conducted a case study to verify the proposed design decision model.

As shown in Figure 1, this study is organized as follows: (Step 1, Section 3) surveys the background works for the parametric study; (Step 2, Section 4) describes performed building energy simulations; (Step 3, Section 5) derives a modeling framework of energy-sensitive residential building passive design factors with its validation process and then an energy-efficient residential building design decision support model based on the heuristic rules is established. 
Figure 1. Research method diagram for energy-efficient design decision support model.

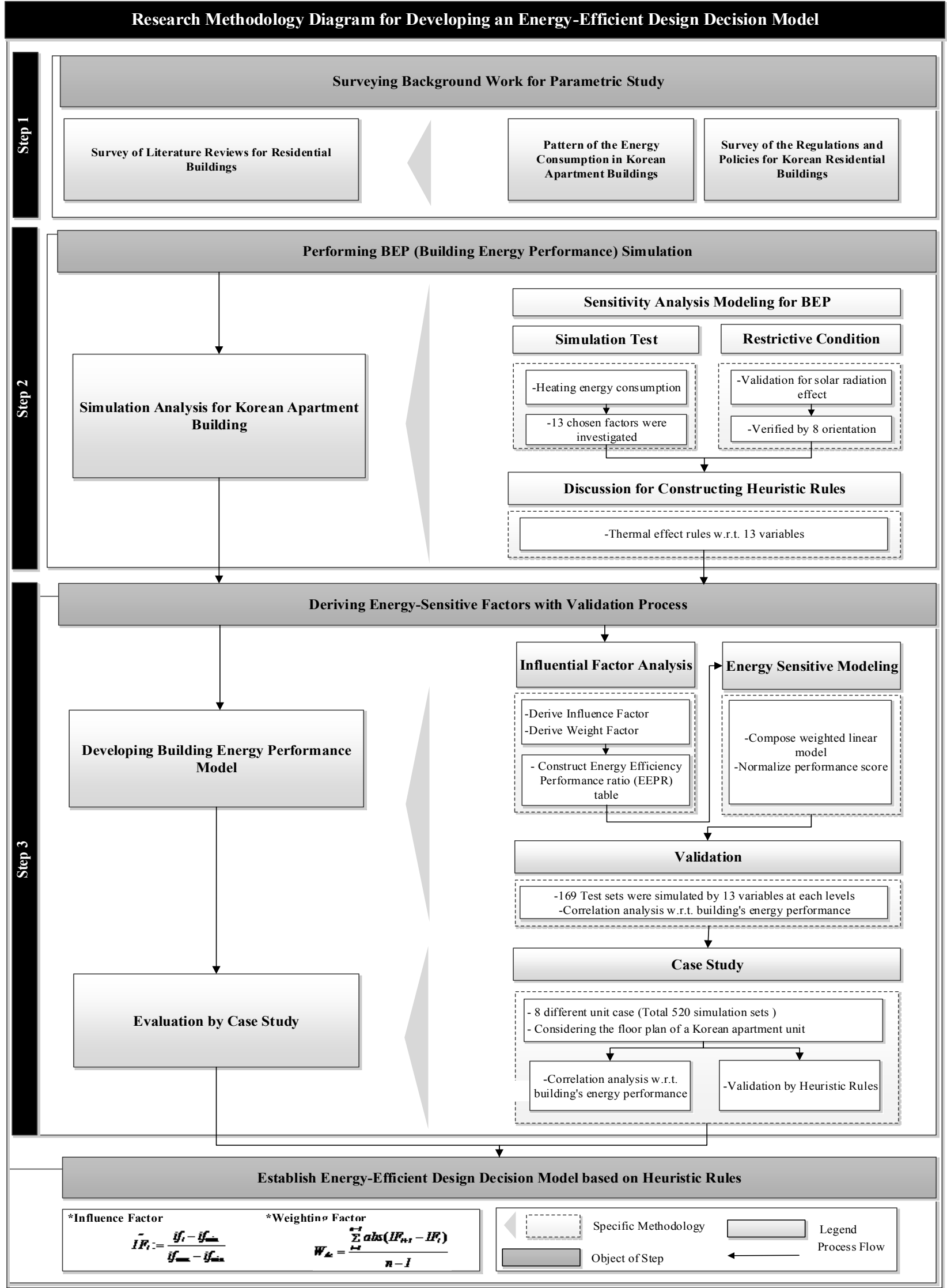




\section{Background Works for Parametric Study}

Candidate technologies must be extracted through an extensive review of the literature, and key parameters for design decision support based on energy sensitive heuristic rules and solutions must be identified before a building energy simulation is performed.

There are many studies on gas and energy consumption issues that consider the major characteristics of apartment buildings [2-9,14-23]. Analyzing the energy sensitive factors of apartment buildings, including the facility and building features, are investigated with a variety of constituents.

Hong [14] analyzed the monthly use of electricity and gas energy along with the level of conservation after occupants' lifestyle changes in apartment complexes. By evaluating energy consumption profiles in relation to the morphological factors of an apartment building [15-18], researchers found that the shape of a building influences the energy usage levels for the heating and cooling load. In addition, Lee [19] explored the current status and characteristics of greenhouse gas emissions through greenhouse gas source unit analyses for local governmental buildings in different regions of Korea according to their usage types (hotels, schools, hospitals and apartment buildings). Besides, diverse study related to thermal load analysis in accordance with the household location [20-22], infiltration, window and balcony types $[23,24]$ have been explored in various ways. Performed literature reviews related to the energy aspect of Korean apartment building are summarized in Table 1.

Table 1. Literature review for building energy study.

\begin{tabular}{|c|c|c|c|c|}
\hline Method & Building types & Energy load & Design variables & References \\
\hline $\begin{array}{l}\text { Empirical } \\
\text { analysis }\end{array}$ & $\begin{array}{l}\text { Apartment } \\
\text { complex }\end{array}$ & $\begin{array}{c}\text { Electricity and Gas } \\
\text { energy consumption } \\
\text { (Heating) }\end{array}$ & $\begin{array}{l}\text { Area size, Number of occupants, } \\
\text { occupant behavior, Elapsed years, } \\
\text { maintenance area, house hold, building type, } \\
\text { Regional information }\end{array}$ & {$[2,5,14]$} \\
\hline $\begin{array}{c}\text { Empirical } \\
\text { analysis }\end{array}$ & Building & Heating energy load & $\begin{array}{l}\text { Orientation, area size, heating type, } \\
\text { Floor plan types, building shapes, } \\
\text { floor plans, usage, occupant's features } \\
\text { and schedule }\end{array}$ & {$[7,15,17-19]$} \\
\hline Simulation & Building & $\begin{array}{l}\text { Heating energy } \\
\text { load, Cooling } \\
\text { energy load }\end{array}$ & $\begin{array}{l}\text { Orientation, floor plan type, window to } \\
\text { wall ratio, shading type, thermal insulation } \\
\text { type, glass type, Unit location, window } \\
\text { type, number of floors, infiltration }\end{array}$ & {$[8,9,20-24]$} \\
\hline
\end{tabular}

Most research related to energy consumption in Korean-style apartment buildings usually focuses on consumption patterns or phenomena analyses, and precedent studies provide clues and insights on appropriately choosing the parameters that influence energy consumption or energy simulation.

For certifying sustainable building design and construction processes, the Leadership in Energy and Environmental Design (LEED) [25] green building rating system was developed by the US Green Building Council (USGBC) to provide a recognized standard for construction, operation, and maintenance of green buildings. In the UK, the Building Research Establishment Environment Assessment Method (BREEAM) [26] which was developed by Building Research Establishment Ltd. (BRE) (Watford, UK) has been used to evaluate sustainable building performance. In Japan, 
the Comprehensive Assessment System for Building Environment Efficiency (CASBEE) [27] is used as a green rating tool for evaluating environmental building performance.

The Korean Government is faced with the necessity of energy reduction in the building sector. In this context, Green Building Certification Criteria (GBCC) [28] has been developed under the guidance of the Ministry of Land, Infrastructure and Transport. Current sustainable building design guidelines and building codes initiated by the government includes the performance and heat transfer of the building envelope, specifically walls and windows, in terms of how this transfer is influenced by the thermal energy load. This is expected to reduce energy consumption and it offers incentives for low-carbon activities. By 2017, the Korean Government plans to strengthen the insulation and airtightness level for low energy use housing to meet the criteria of thermal insulation of the Passive Houses standard [28].

\section{Building Energy Simulation for Korean Apartment Housings}

The fundamental methodological framework of this research was based on our precedent study on the systematic investigation for the heuristically extractable relationships between residential building design parameters and energy consumption profiles [8]. First, this study focuses on a chosen set of energy sensitive passive building design factors which indicate the thermal energy performance of the selected building design features and technologies. Weight factors are derived from extensive sensitivity analysis based on building energy simulations. We evaluated the results of the energy sensitivity analysis, which are summarized in a set of heuristic rules for evaluating architectural design features, through case studies of Korean apartment floor plans. In addition, various restrictive and mixed design conditions between each of the heuristic rules are also verified through a number of simulation test sets.

\subsection{Sensitivity Analysis for Building Energy Simulation}

This study performs a perturbed analysis from a base case to retrieve influential coefficients of each building parameter as a difference percentage of change in the output due to the percentage of perturbation in the input. Sensitivity coefficients may be determined on the basis of any number of simulation results [10-13]. Even using the same output results, the sensitivity coefficient may be expressed in various forms. In this study, a base case with some default values was necessary as a reference against which the alternatives could be measured. Therefore, in this study, we used the form of the sensitivity coefficient as in Equation (1), which is known as the most useful sensitivity assessment for performing building energy simulation methods [10], is employed in this study:

$$
I C=\frac{\Delta O R \div O R_{B C}}{\Delta I P \div I P_{B C}}
$$

where $\triangle O R$ and $\triangle I P$ are changes in the output result and input parameter, respectively, and $O R_{B C}$ and $I P_{B C}$ are the values of the input and output of the base case. This sensitivity coefficient is a dimensionless value represented by the percentage of changes in the output results in a percentage of perturbation in the input. This equation uses the base case value to express the sensitivity in percentage change.

The goal of sensitivity analysis is to minimize building energy load and to accomplish the best energy efficiency in accordance with critical building design variables. Most of building energy studies adopted 
a constrained optimization because there are often physical and practical limitations on the input design parameters [10-12].

It is said that the problem statement can be theoretically interpreted in a practical problem definition if the variables involved can be a determined explicit or implicit form. For thermal interactions between building variables based on building physics problems, it is unable to describe the physical phenomena by simple mathematical relationships since descriptions and relationships are so abstract and complicated [10-13,22,23].

Therefore, it is also argued that the problem definition for a building energy study cannot be stated out clearly. Unlike mathematical problems, energy modelling is usually carried out abstractly [10,11]. A clear understanding of the practical implications and limitations should be considered in the analysis of building energy simulation along with the quantitative approach.

Precedent researches pointed out that specific building model conditions need to be formulated with the modelling assumptions as well as an understanding of the simulation process and the practical implications before performing the building energy simulation $[10,11,23]$.

The procedure of this study is demonstrated as below:

(1) Select input design parameters that should be identified and analyzed.

(2) Build a base case as a reference model.

(3) Identify parameters of interest and investigate a base case values.

(4) Determine what simulation outputs are to be investigated and expect the outputs.

(5) Perform perturbations to the selected parameters about their base case values one at a time.

(6) Study the corresponding influence of input parameters on different simulation outputs.

(7) Determine the sensitivity coefficients for each parameter.

(8) Perform a validation process regarding completed simulation results.

(9) Perform a case study.

(10) Construct energy-efficient heuristic rules.

\subsection{Simulation Environment}

This study analyzes and simulates an individual housing unit of apartment complexes to reveal how passive design elements are affected by heating load. Therefore, performance analysis of shared facilities such as boilers, chillers and lighting devices are excluded from the scope of this research.

A passive house is a building designed for energy efficiency primarily in space heating and cooling through the use of advanced insulation and other passive design solutions that maximizes energy saving. We selected the design parameters from extensive reviews of Korean apartment housing related to building energy [2-9,14-33] as well as expert interviews. Our investigations focused on the properties of building structure, such as building frames and building skin, and considered heat transfer such as conduction (wall concrete/insulation thickness, wall insulation location, window construction, balcony type/depth, plan proportion, floor area size, unit location and internal wall placement), convection (air exchange rate), and radiation (orientation, plan proportion, window to wall ratio, window construction, balcony depth, unit location and internal wall placement) found in a typical residential space in the Korean climate. 
In the perturbation study, we considered annual heating energy consumption as the time interval for analysis. If time series factors are involved, the perturbation analysis is more complicated and it is necessary to base the analysis on mathematical and statistical techniques [9].

The simulation tests were performed using DesignBuilder, a user-friendly modeling environment that calculates building energy consumption including heating or cooling energy load. This calculation is based on detailed sub-hourly simulation time steps using the EnergyPlus simulation engine. It is important to note that this study focuses on the interpretation of simulation results and not on the simulation method $[34,35]$.

From expert interviews and a literature review on the selection of a typical Korean apartment floor plan, the representative floor plan shown in Figure 2 was chosen for analysis [31-33].

Figure 2. (a) Floor plan for the simulation; (b) flat style apartment model with fifteen stories.
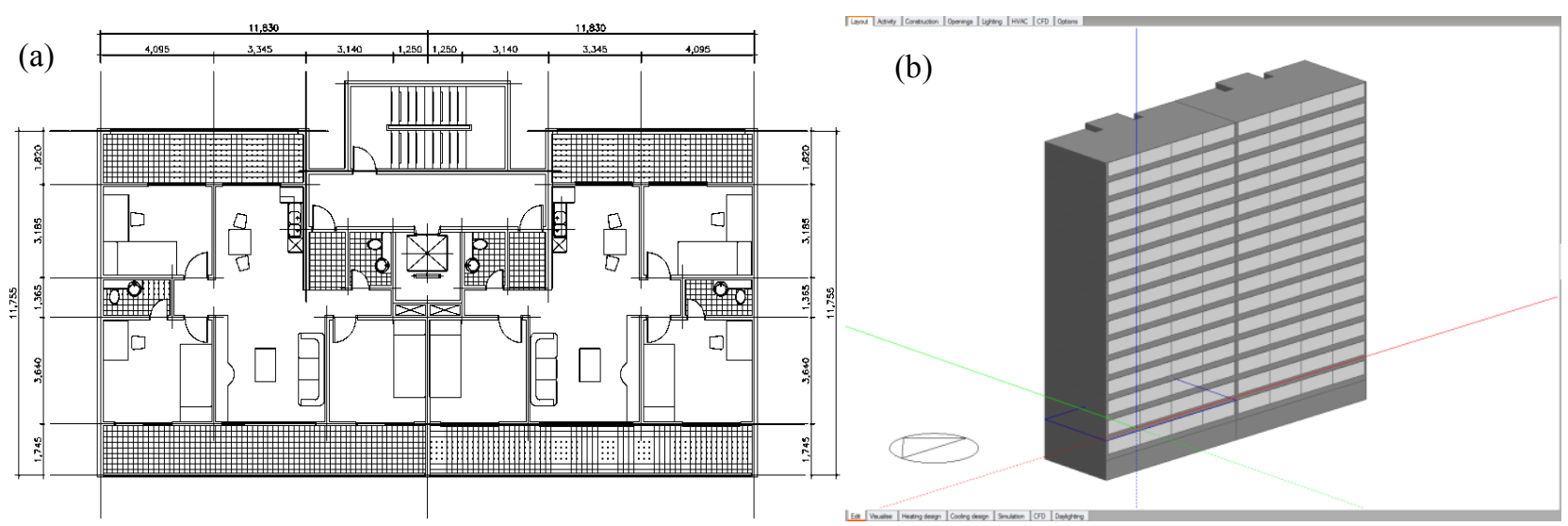

The floor area was $85 \mathrm{~m}^{2}$, excluding the building's public areas, and the ceiling height was $2.7 \mathrm{~m}$. Balcony types and area were specified in the test cases. While Korean apartments typically employ underfloor radiant heating, the presence of residential cooling systems is a matter of user choice.

Active system and individual appliances also could not be encompassed in this research as our focus is on the development of a heuristic rule based passive design decision support model based on numerous instances of preprocessed building energy sensitivity simulations.

The activity schedule of a working class family of four people was defined based on the demographically typical Korean family. ASHRAE International Weather for Energy Calculations (IWEC) data for Seoul, Korea was used as climate information in this simulation. An illuminance condition of 150 lux was set [36]. The materials selected were those commonly used in the construction of Korean multi-story residential buildings. Details of the material properties, layer arrangement and test cases are included in Table 2.

The analyzed parameters were sequentially changed while the reference test case remained fixed. The relative energy sensitivity of target components was derived from the resulting simulation test sets. 
Table 2. Standard condition for the simulation test.

\begin{tabular}{|c|c|c|}
\hline Component & Material & U-value \\
\hline External Wall & $\begin{array}{c}\text { Concrete, Reinforced (with } 2 \% \text { steel) } 180 \mathrm{~mm} \\
\text { XPS Extruded Polystyrene- } \mathrm{CO}_{2} \text { Blowing } 120 \mathrm{~mm} \\
\text { Gypsum Plastering } 9.5 \mathrm{~mm}\end{array}$ & $0.263 \mathrm{~W} / \mathrm{m}^{2} \cdot \mathrm{K}$ \\
\hline Internal Wall & $\begin{array}{c}\text { Gypsum Plastering } 9.50 \mathrm{~mm} \\
\text { Concrete, Reinforced (with } 2 \% \text { steel) } 150 \mathrm{~mm} \\
\text { Gypsum Plastering } 9.50 \mathrm{~mm}\end{array}$ & $2.525 \mathrm{~W} / \mathrm{m}^{2} \cdot \mathrm{K}$ \\
\hline Flat Floor & $\begin{array}{l}\text { Cement/plaster/mortar-render, synthetic resin, } \\
\text { exterior insulation } 400 \mathrm{~mm} \\
\text { XPS Extruded Polystyrene- } \mathrm{CO}_{2} \text { Blowing } 300 \mathrm{~mm} \\
\text { Concrete, Reinforced (with } 2 \% \text { steel) } 200 \mathrm{~mm} \\
\text { Air gap } 25 \mathrm{~mm} \text { (downwards) } 25 \mathrm{~mm} \\
\text { Gypsum Plasterboard } 9.5 \mathrm{~mm}\end{array}$ & $0.659 \mathrm{~W} / \mathrm{m}^{2} \cdot \mathrm{K}$ \\
\hline Ground Floor & $\begin{array}{l}\text { Cement/plaster/mortar-render, synthetic resin, } \\
\text { exterior insulation } 40 \mathrm{~mm} \\
\text { XPS Extruded Polystyrene- } \mathrm{CO}_{2} \text { Blowing } 85 \mathrm{~mm} \\
\text { Concrete, Reinforced (with } 2 \% \text { steel) } 200 \mathrm{~mm} \\
\text { Air gap } 25 \mathrm{~mm} \text { (downwards) } 25 \mathrm{~mm} \\
\text { Gypsum Plasterboard } 9.5 \mathrm{~mm} \\
\end{array}$ & $0.319 \mathrm{~W} / \mathrm{m}^{2} \cdot \mathrm{K}$ \\
\hline Roof & $\begin{array}{c}\text { Cast Concrete } 50 \mathrm{~mm} \\
\text { XPS Extruded Polystyrene- }-\mathrm{CO}_{2} \text { Blowing } 180 \mathrm{~mm} \\
\text { Concrete, Reinforced (with } 2 \% \text { steel) } 180 \mathrm{~mm} \\
\text { Air gap } 25 \mathrm{~mm} \text { (downwards) } 25 \mathrm{~mm} \\
\text { Gypsum Plasterboard } 95 \mathrm{~mm} \\
\end{array}$ & $0.173 \mathrm{~W} / \mathrm{m}^{2} \cdot \mathrm{K}$ \\
\hline HVAC & $\begin{array}{l}\text { Under Floor Heating System } \\
\text { Air Conditioner Cooling }\end{array}$ & $\begin{array}{l}\text { Heating Set point: } 21.0^{\circ} \mathrm{C} \\
\text { Cooling Set point: } 26.0^{\circ} \mathrm{C}\end{array}$ \\
\hline Window Type & Glazing Type & $\begin{array}{c}\text { Glazing Double Clear } 3 \mathrm{~mm} / 13 \mathrm{~mm} \\
\text { Air; U-Value: } 2.761 \mathrm{~W} / \mathrm{m}^{2} \cdot \mathrm{K} \\
\text { SHGC: } 0.764 \\
\text { Southern balcony: } 70 \% \\
\text { Northern balcony: } 40 \%\end{array}$ \\
\hline Air Exchange Rate & \multicolumn{2}{|c|}{$0.7 \mathrm{ac} / \mathrm{h}$ (on the basis of living room) } \\
\hline Lighting & \multicolumn{2}{|c|}{ Lighting Power Density: $5.0 \mathrm{~W} / \mathrm{m}^{2}$ (Fluorescent) } \\
\hline Occupancy & \multicolumn{2}{|c|}{0.05 people $/ \mathrm{m}^{2}$ (on the basis of living room) } \\
\hline Base model location & Bottom-outside (1st floor/ 15 stori & s, 60 Households) \\
\hline
\end{tabular}

\subsection{Discussion about Simulation Outcomes}

The perturbation studies were based on a systematic sensitivity analysis for identifying the thermal influence of input design parameters on various simulation outputs in relation to a base case situation. Tables 3 and 4 present building energy simulation conditions and input parameters for the evaluation. A set of parameter information and criteria for ranging design parameters for the building energy simulation is described in Table 5. The simulation results based on sensitivity analysis are shown below: 
Table 3. Glass type for test set.

\begin{tabular}{ccc}
\hline Glass type & U-Value & SHGC \\
\hline Sgl Clr 3 mm & 6.257 & 0.861 \\
Sgl Loe $(\mathrm{e} 2=.4)$ Clr 3 mm & 4.945 & 0.781 \\
Dbl Clr 3 mm/13 mm Air & 2.761 & 0.764 \\
Dbl LoE (e2 =.1) Clr 3 mm/13 mm Air & 1.798 & 0.598 \\
Trp Clr 3 mm/13 mm Air & 1.778 & 0.684 \\
Trp LoE (e5 $=.1) 3 \mathrm{~mm} / 13 \mathrm{~mm}$ Air & 1.270 & 0.579 \\
\hline
\end{tabular}

Table 4. Input parameters for simulation test sets.

\begin{tabular}{|c|c|c|}
\hline Test Num. category & Test description & Test set \\
\hline T.1 Orientation & $\begin{array}{l}\text { Eight cardinal directions were iterated from the base case, } \\
\text { in which the balcony faces south }\end{array}$ & $\begin{array}{l}\text { N, NW, W, SW, S, } \\
\text { SE, E, NE }\end{array}$ \\
\hline T.2 Air exchange rate & $\begin{array}{l}\text { The air change rate is the volumetric flow rate of outside air into a } \\
\text { building, typically in cubic feet per minute or liters per second }\end{array}$ & $0.3,0.4,0.5,0.6,0.7(\mathrm{ac} / \mathrm{h})$ \\
\hline T.3 Insulation location & $\begin{array}{l}\text { The insulation type is decided by the location of the insulation } \\
\text { material layer, whether interior or exterior }\end{array}$ & Interior, Exterior (Lyr) \\
\hline $\begin{array}{l}\text { T.4 Wall Thickness } \\
\text { (concrete) }\end{array}$ & Concrete thickness is evaluated from $100 \mathrm{~mm}$ to $300 \mathrm{~mm}$ & $\begin{array}{l}100,150, \mathbf{2 0 0} \\
250,300(\mathrm{~mm})\end{array}$ \\
\hline $\begin{array}{l}\text { T.5 Wall Thickness } \\
\text { (insulation) }\end{array}$ & Insulation thickness is evaluated from $100 \mathrm{~mm}$ to $300 \mathrm{~mm}$ & $\begin{array}{l}\mathbf{1 0 0}, 150,200 \\
250,300(\mathrm{~mm})\end{array}$ \\
\hline $\begin{array}{l}\text { T.6 Window to } \\
\text { Wall Ratio }\end{array}$ & As the window area on the south façade is assessed & $\begin{array}{c}50 \%, 60 \%, 70 \%, 80 \% \\
90 \%, 100 \%\end{array}$ \\
\hline T.7 Glass type & $\begin{array}{l}\text { Six window types were simulated herein in an iterative test to } \\
\text { investigate the effect of combinations of glazing layers on } \\
\text { energy load }\end{array}$ & $\begin{array}{c}\text { single-clear/loe, } \\
\text { double-clear/loe, } \\
\text { triple-clear/loe }\end{array}$ \\
\hline T.8 Floor Area & $\begin{array}{l}\text { Residential unit's width and length are changed while keeping } \\
\text { other proportion such as window to wall ratio, and plan proportion }\end{array}$ & $\begin{array}{c}45,55,65,75, \mathbf{8 5}, 95 \\
105,115,125,135\left(\mathrm{~m}^{2}\right)\end{array}$ \\
\hline T.9 Plan proportion & Horizontal to Vertical ratio & $\begin{array}{c}\mathbf{1}: 1,1.25: 1,1.5: 1 \\
1.75: 1,2: 1 \\
\end{array}$ \\
\hline T.10 Balcony Type & Two balcony types are common in Korean apartments & $\begin{array}{l}\text { Room extension, } \\
\text { Closed type }\end{array}$ \\
\hline T.11 Balcony Depth & Vertical length between external balcony and inner window & $\begin{array}{l}1,1.25, \mathbf{1 . 5}, 1.75,2(\mathrm{~m}) \\
\text { the basis of southern } \\
\text { balcony }\end{array}$ \\
\hline T.12 Unit Location & $\begin{array}{l}\text { This test explored energy consumption patterns based on a } \\
\text { unit's exposure to outside air, with exposure iterated }\end{array}$ & $\begin{array}{l}\text { Top-inside/outside, } \\
\text { Middle-inside/outside, } \\
\text { Bottom-inside/outside }\end{array}$ \\
\hline $\begin{array}{c}\text { T.13 Internal } \\
\text { wall placement }\end{array}$ & $\begin{array}{l}\text { H1: Internal wall vertically placed to solar radiation is far from } \\
\text { external balcony facing south } \\
\text { H2: Internal wall vertically placed to solar radiation is located } \\
\text { in the middle of the zone } \\
\text { H3: Internal wall vertically placed to solar radiation is closer to } \\
\text { external balcony facing south }\end{array}$ & $\mathrm{H} 1, \mathbf{H} 2, \mathrm{H} 3$ \\
\hline
\end{tabular}


Table 5. Criteria for ranging design parameters to perform building energy simulations.

\begin{tabular}{|c|c|}
\hline Design parameters & Description \\
\hline Orientation & Eight orientations are evaluated. \\
\hline Air exchange rate & $\begin{array}{l}\text { Korean building regulation recommends that all Korean apartment housing } \\
\text { must fulfill air change rate of over } 0.7 \mathrm{ac} / \mathrm{h} \text { (air change per hour). } \\
\text { Besides, super-insulated housing has air change rate of over } 0.3 \sim 4 \mathrm{ac} / \mathrm{h} \text {. } \\
\text { Therefore, this study uses the range between } 0.3 \mathrm{ac} / \mathrm{h} \text { and } 0.9 \mathrm{ac} / \mathrm{h} \text {. }\end{array}$ \\
\hline Insulation location & Two typical insulation associated construction types are evaluated. \\
\hline Wall concrete thickness & $\begin{array}{l}\text { Concrete thickness of base case building model is selected according to the } \\
\text { guideline of the insulation criteria for Korean apartment complexes [30-32]. } \\
\text { In addition, range variation from } 300 \mathrm{~mm} \text { to } 100 \mathrm{~mm} \text { is chosen for the } \\
\text { representative wall thickness selections, considering super insulation case as } \\
\text { well as the lowest constraint of concrete thickness. }\end{array}$ \\
\hline Wall insulation thickness & $\begin{array}{l}\text { Insulation thickness of base case building model is selected according to } \\
\text { the wall insulation regulation for Korean apartment complexes [33]. } \\
\text { Besides, variation from } 250 \mathrm{~mm} \text { to } 50 \mathrm{~mm} \text { (typically } 200 \mathrm{~mm} \text { ) is selected as the } \\
\text { assesment range according to the expert interviews and other precedent studies. }\end{array}$ \\
\hline Window to wall ratio & $\begin{array}{l}\text { Considering the limitation of simulation tool, relative window area for the } \\
\text { balcony facing south is considered to represente window to wall ratio. } \\
\text { From the researches of }[24,31] \text { as well as expert interviews regarding } \\
\text { Korean apartment floor plans, } 70 \% \text { is selected as the base case. }\end{array}$ \\
\hline Window type & $\begin{array}{l}\text { Glass that meets the environmental friendly glass property criteria in Korea is } \\
\text { selected for the analyses. Because Korean government requires U-value of } \\
1.5 \mathrm{~W} / \mathrm{m}^{2} \cdot \mathrm{K}[5] \text {, double and triple low-e glazing that satisfy this criterion, } \\
\text { are selected. For varying total thermal conductivity through glazing, the range } \\
\text { from single clear glazing all the way up to triple low-e glazing is selected to } \\
\text { investigate the energy sensitivity of different glazing types. }\end{array}$ \\
\hline Floor area size & $\begin{array}{l}\text { Considering the literature [31] as well as expert interviews, representative floor } \\
\text { area size is chosen and this floor area size is also evaluated. }\end{array}$ \\
\hline Plan proportion & $\begin{array}{l}\text { Based on the prevalent shapes of housing units in Korea, total five different plan } \\
\text { proportions are selected and evaluated by the case studies. }\end{array}$ \\
\hline Balcony type & Two commonly practiced balcony types in Korean apartments are evaluated. \\
\hline Balcony depth & $\begin{array}{l}\text { The regulation recommends that Korean apartment housing must have the } \\
\text { balcony depth within } 2 \text { meters. Therefore, the balcony depth is evaluated by } \\
\text { varying the range between } 1 \text { and } 2 \text { meters with respect to the typical } \\
\text { Korean apartment floor plan. }\end{array}$ \\
\hline Unit location & $\begin{array}{l}\text { Six different location is evaluated by considering a unit's location in an } \\
\text { apartment building. }\end{array}$ \\
\hline Internal wall placement & $\begin{array}{l}\text { According to literature [9] as well as expert interviews, three different internal } \\
\text { wall placement cases are evaluated. }\end{array}$ \\
\hline
\end{tabular}

\subsubsection{Orientation (T.1)}

For the orientation test, eight cardinal directions were iterated from the base case in which the balcony faced south. As expected, the south-facing balcony experienced the least energy load with a heating energy load of $45 \%$ less than that of a northerly orientation as illustrated in Table 6. 
Table 6. Annual heating energy consumption with test variables.

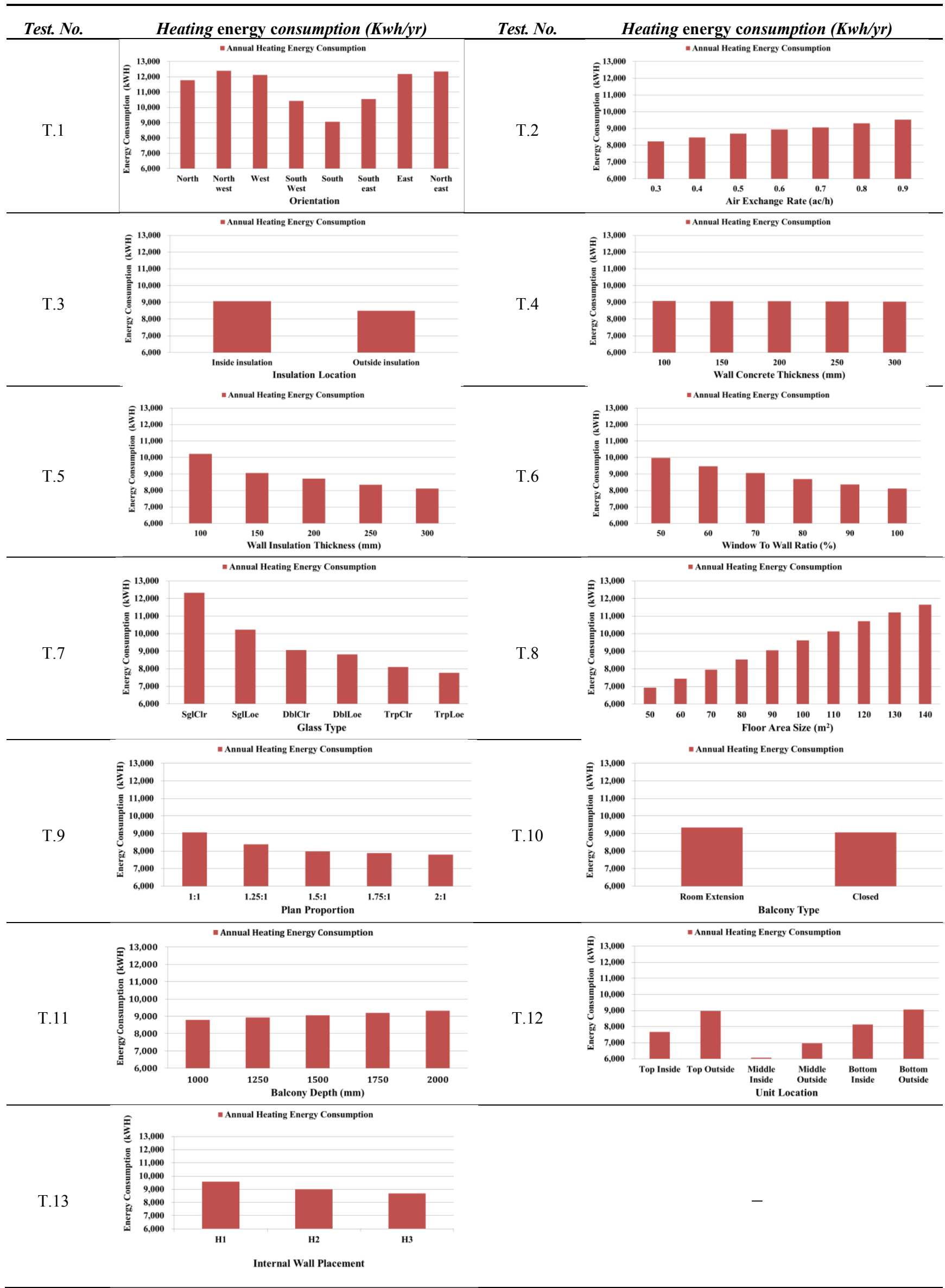




\subsubsection{Air Exchange Rate (T.2)}

The building facility regulations recommend that all Korean apartments must have an air exchange rate of over 0.7 air exchange per hour $(\mathrm{ac} / \mathrm{h})$, where the air exchange rate is the number of interior volume air changes that occur per hour in units of $1 / \mathrm{h}$.

The results show that as the air exchange rate increased from $0.3 \mathrm{ac} / \mathrm{h}$ to $0.9 \mathrm{ac} / \mathrm{h}$, heating energy consumption increased by $15 \%$. Low air exchange rates were associated with more efficient energy profiles in heating energy consumption.

\subsubsection{Insulation Location (T.3)}

The insulation type is determined by the location of the insulation material layer, whether interior or exterior. Exterior insulation minimizes thermal bridge break. However, Korean apartments generally use interior insulation because of construction issues. The test results show that exterior insulation provides superior energy efficiency, with interior insulation providing the worst. For the analysis, the energy effect of the insulation placement and energy consumption pattern was analyzed by changing the insulation placement while keeping the insulation material and thickness fixed.

\subsubsection{Wall Thickness (Concrete) (T.4)}

As expected, increasing the wall thickness to $300 \mathrm{~mm}$ from $100 \mathrm{~mm}$ decreased the heating energy consumption. In particular, the heating load results showed a small decrease when the wall thickness was increased.

\subsubsection{Wall Thickness (Insulation) (T.5)}

Our test results revealed that the energy load changed with insulation thickness. As with concrete cases, when the insulation thickness increased from $50 \mathrm{~mm}$ to $250 \mathrm{~mm}$, the heating energy load decreased as shown in Table 6.

\subsubsection{Window to Wall Ratio (T.6)}

As the window area on the south facade increased, the heating energy consumption decreased. Through a larger window area, the solar heat gain has a greater impact on heating energy consumption than heat transfer loss.

\subsubsection{Glass Type (T.7)}

Glass that met the environmental friendly glass property criteria in Korea was selected for the analyses. Because the Korean government requires a U-value of $1.5 \mathrm{~W} / \mathrm{m}^{2} \cdot \mathrm{K}$ [5], double and triple low-e glazing that satisfy this criterion were selected as shown in Tables 4 and 5. Six window types were simulated in an iterative test to investigate the effect of combinations of glazing layers on energy load. Table 6 shows that the number of glazing layers and coating type proved influential in energy conservation. Triple-layer and low-e coated glazing cut heating energy consumption by $58 \%$ compared 
to single-layer glazing. However, it is necessary to consider the trade-off between reduced energy savings and the cost of construction materials.

\subsubsection{Floor Area (T.8)}

As one might expect, energy consumption increased as the area increased, as shown in Table 6 . This test set changed the residential unit width and length while keeping other proportions such as window to wall ratio and the plan proportion.

\subsubsection{Plan Proportion (Horizontal to Vertical Ratio) (T.9)}

We analyzed the effect of a residential unit's proportion of width to length. As described above, Korean apartment design plans do not have much diversity. The heating energy consumption decreased as the ratio of width to length increased due to an increased solar heat gain.

\subsubsection{Balcony Type (T.10)}

Currently, two balcony types are common in Korean apartments: room extension and closed. The room extension balcony functions as an extension of an inner space to attain more living area. By contrast, the closed balcony forms a separate space via exterior and interior glazing layers and is not cooled or heated.

Table 6 illustrates that the closed balcony offers a better energy efficiency profile than the room extension, based on its increased insulation and relatively less area requiring heating energy load.

\subsubsection{Balcony Depth (T.11)}

Iterations of balcony depth test reveal opposite energy load patterns, primarily because balcony depth is largely affected by annual solar gain. The test case for balcony depth was simulated for the closed balcony only. Table 6 shows that the heating energy consumption increased slightly with the increment of balcony depth.

\subsubsection{Unit Location (T.12)}

According to [20-22], the gas heating load of a Korean apartment building differs greatly depending on what floor the unit is on, as well as the number of floors. The ground floor carries a $29.4 \%$ greater heating energy load than the middle floor, and top floors a 5.9\% greater heating load. The greater load for ground floors may be attributed to under-floor heating loss to ground heat.

Housing units also have different heating energy loads based on the exterior area exposed to outside air, with apartments that are more externally exposed consuming much more energy. This test explored energy consumption patterns based on a unit's exposure to outside air, with exposure iterated as follows: bottom-outside, bottom-inside, middle-outside, middle-inside, top-outside, and top-inside. Table 6 presents energy consumption patterns considering a unit's location. 


\subsubsection{Internal Wall Placement (T.13)}

The systematic sensitivity analysis on various types of internal wall placement influencing heating energy load pattern is explored in this test set and include the impact of different intersectional placement attributes of the internal walls, such as horizontal placement. The main issue of this test set is based on the difference and comparison of solar radiation penetration which enters the south side window and thermal loss due to internal wall arrangement variations [9].

Table 6 shows the result of a gradually changing horizontal wall towards the southern window side to confirm its impact on the heating load profile. The heating load decreased when the internal wall that is vertically placed to solar radiation is closer to the external balcony facing south. On the other hand, the amount of heating load increased when the distance between the internal wall and the external balcony increased. This result may be caused by solar radiation warming up indoor air and thermal loss due to the buffer space between the internal wall and external windows directly hitting the internal wall and triggering a regenerative heat phenomenon.

\subsection{Validation Test for Solar Radiation}

In the first step of the simulation analysis, we selected target parameters relating to heat conduction, convection and solar radiation. Solar radiation affects space heating in buildings, and the building orientation decides the amount of radiation it receives. Therefore, we performed solar radiation testing as a restrictive test case to confirm whether the induced heuristic rules for thermal response are suitable in every orientation case or not.

In this step, to verify the effect of solar radiation regarding insolation effective variables, each parameter of all 13 cases were tested by iterating the orientation so that the variables we thought might be affected by insolation could be verified.

According to the results shown in Table 7 all the test sets for heating energy load, such as "window to wall ratio", "plan proportion", and "internal wall placement", show distinct increasing or decreasing patterns in the northeast, northwest, and north cases. Therefore, it is necessary to carefully design heuristic rules regarding these constraints to build general design rules.

Table 7. Restrictive condition tests for verifying solar radiation effect.

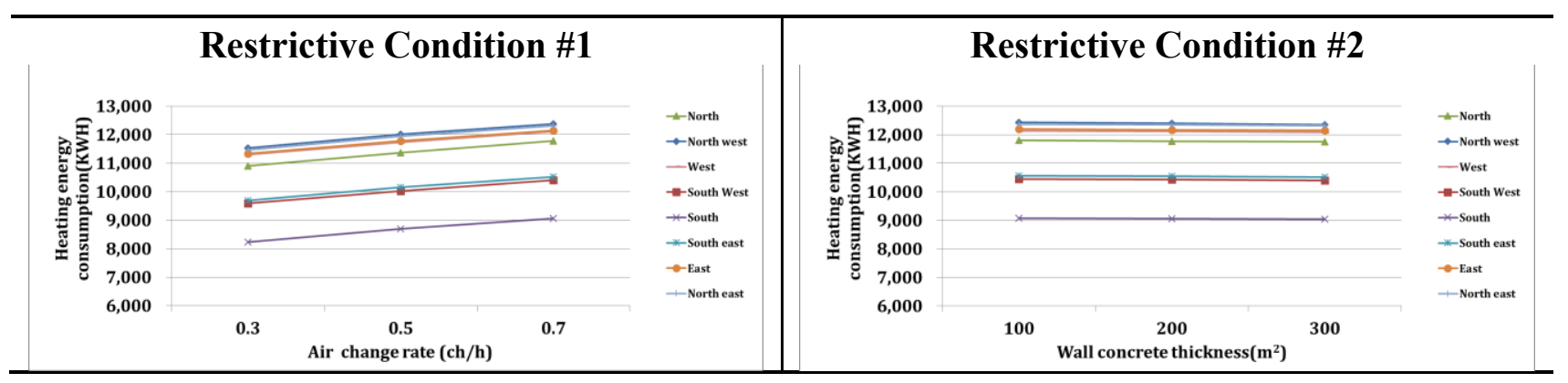


Table 7. Cont.

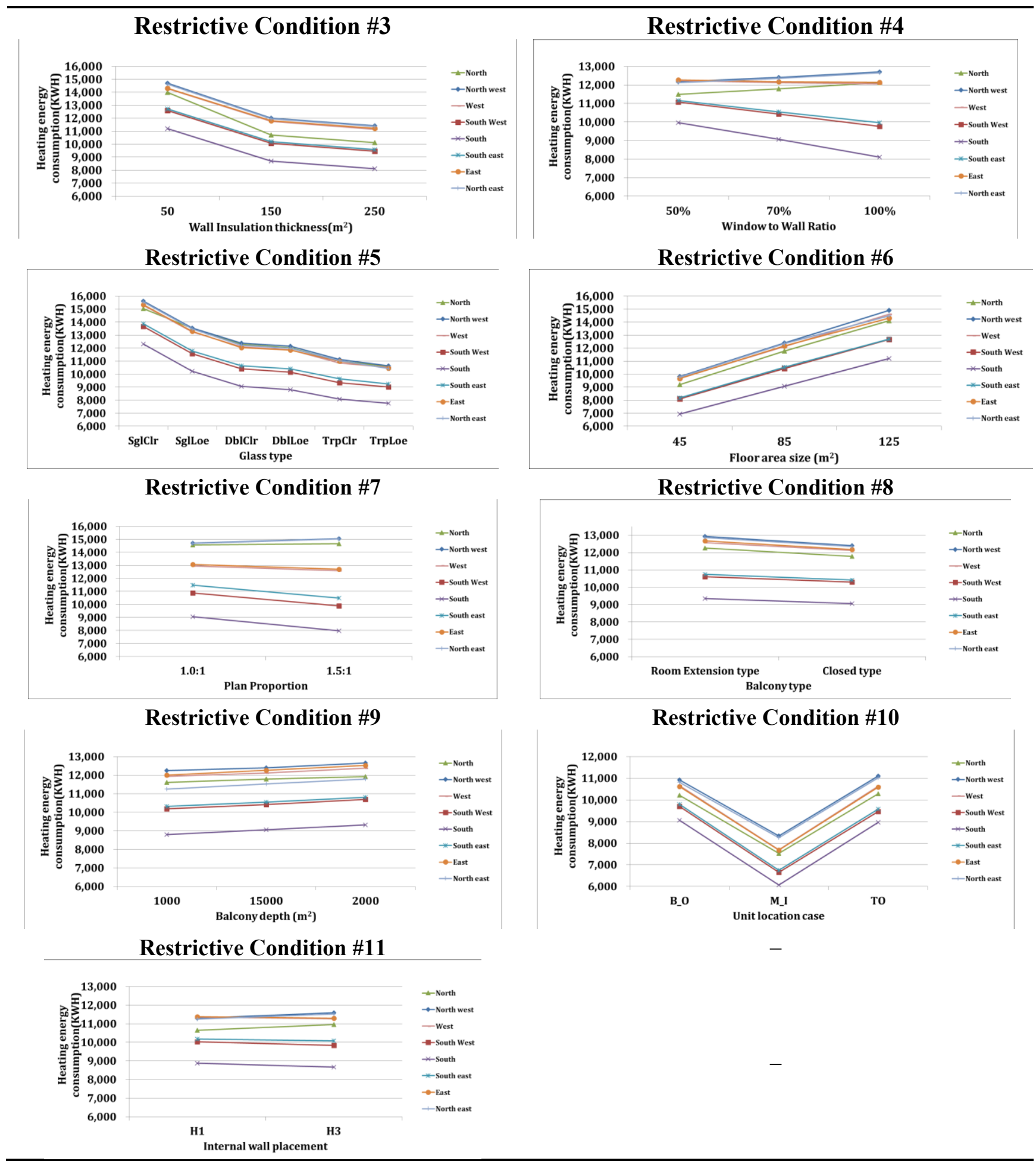

\subsection{Discussion for Constructing Heuristic Rules}

The results of the energy sensitivity analysis can be summarized in a set of heuristic rules for evaluating architectural features with regard to maximizing energy performance. The heuristic rules thus developed for the energy sensitivity of passive design schemes will greatly facilitate design decision-making. 


\section{Deriving Energy—Sensitive Factors with Validation Process}

Based on the absolute value of the energy load of each component, including heating energy consumption, the energy sensitive factors that indicate the energy performance of each building design component can be derived from the normalized calculation of the energy consumption of each.

\subsection{Developing Building Energy Performance Model}

\subsubsection{Influential Factor Analysis}

\subsubsection{Influence Factor}

The influence factor of each passive building design component is converted to normalized values to keep the range between 0 and 1, and these values are used as energy sensitive factors for each building design component:

$$
\text { Influenc̃e }_{\text {Factor }}=\frac{\text { influence } \text { factor }_{i}-\text { influence }_{\text {factor }} \text { min }}{\text { influence } \text { factor }_{\max }-\text { influence }_{\text {factor }}}
$$

where influence factor ${ }_{\text {min }}$ is the minimum value among the influence factors of all the design parameters, and influence factor $r_{\max }$ is the maximum value among the influence factors of all the design parameters. The normalized influence factor values for the selected building parameters should be analyzed respectively into single representative energy factors and they must be evaluated based on the estimated energy efficiency of the designed building as affected by the user choices.

\subsubsection{Weighting Factor}

To achieve energy sensitivity in accordance with changing design parameters, it is necessary to analyze the design priority of each design parameter considering the impact of design choices on energy efficient building design. Therefore, the influence on the building thermal response of each design parameter should be calculated:

$$
W_{d p}=\frac{\sum_{i=1}^{n-1} a b s\left(\text { Influence } \text { Factor }_{i+1}-\text { Influence Factor }_{i}\right)}{n-1}
$$

where $W$ is weighting variable; $d p$ denotes the design parameter, and each of these means the averaged differential influence of the design parameters. Meanwhile, $n$ is the number of each design component of each design parameter and $i$ is a design component.

Parameters are sorted from the highest influence coefficient to the lowest as shown in Table 8. The designer should focus on the highest influence coefficient for further adjustment during design. For example, changing the orientation would have more impact on building performance than increasing or decreasing concrete wall thickness.

In addition, Table 8 present the influence of the selection of each design parameter on the building thermal response. Each of the percent reduction is relative to the most energy efficient case at each design parameter. The thermal influence of southern orientation, for example, would bring approximately $36.78 \%$ more energy efficiency than a northern orientation. These variables define 
specific design selections of the building and determine the areas of the various elements constituting the external envelope.

Table 8. Weighting factor for heating energy consumption.

\begin{tabular}{cc}
\hline Design parameter & Weighting factor \\
\cline { 2 - 2 } Orientation & Heating energy consumption \\
Unit Location & 1.1424 \\
Glass Type & 1.1368 \\
Floor Area & 0.7194 \\
Wall thickness (Insulation) & 0.6619 \\
Window to Wall Ratio & 0.3322 \\
Air Exchange Rate & 0.2935 \\
Plan Proportion & 0.2051 \\
Internal Wall Placement & 0.1989 \\
Insulation location & 0.1426 \\
Balcony depth & 0.0900 \\
Balcony type & 0.0847 \\
Wall thickness (concrete) & 0.0445 \\
\end{tabular}

\subsubsection{Energy Performance Modeling}

We developed an energy evaluation model for Korean apartment housing to evaluate energy performance based on heuristic rules without performing energy simulations. According to the use of the Influence Factor, as well as the Energy Efficiency Performance Ratio (EEPR) described in Table 9, the proposed energy performance equation of the metric below reflects the building energy performance:

$$
\begin{aligned}
E P M o d e l & =W_{T 1}\left(E E P R_{T 1}^{\text {target }}-E E P R_{T 1}^{h r}\right)+W_{T 2}\left(E E P R_{T 2}^{\text {target }}-E E P R_{T 2}^{h r}\right) \\
& +W_{T 3}\left(E E P R_{T 3}^{\text {target }}-E E P R_{T 3}^{h r}\right)+W_{T 4}\left(E E P R_{T 4}^{\text {target }}-E E P R_{T 4}^{h r}\right) \\
& +W_{T 5}\left(E E P R_{T 5}^{\text {target }}-E E P R_{T 5}^{h r}\right)+W_{T 6}\left(E P R_{T 6}^{\text {target }}-E E P R_{T 6}^{h r}\right) \\
& +W_{T 7}\left(E E P R_{T 7}^{\text {target }}-E E P R_{T 7}^{h r}\right)+W_{T 8}\left(E E P R_{T 8}^{\text {target }}-E E P R_{T 8}^{h r}\right) \\
& +W_{T 9}\left(E E P R_{T 9}^{\text {target }}-E E P R_{T 9}^{h r}\right)+W_{T 10}\left(E E P R_{T I 1}^{\text {target }}-E E P R_{T 10}^{h r}\right) \\
& +W_{T 11}\left(E E P R_{T 11}^{\text {target }}-E E P R_{T 11}^{h r}\right)+W_{T 12}\left(E E P R_{T 12}^{\text {target }}-E E P R_{T 12}^{h r}\right) \\
& +W_{T 13}\left(E E P R_{T 13}^{\text {target }}-E E P R_{T 13}^{h r}\right)
\end{aligned}
$$

where EPModel is the energy performance model, $W_{T 1}-W_{T 13}$ is the weighting coefficient value indicating the influence of each building design parameter on building thermal response, EEPR target is the Energy Efficiency Performance Ratio value of the target parameter to be evaluated and EEPR $R_{h}$ is the energy efficiency performance ratio value of the highest rank in each design parameter. The restrictive condition "Northeast" $\leq W_{o r} \leq$ "Northwest" were imposed as $W_{W w r}, W_{P r}$, and $W_{I w}$ for estimation precision. The building energy performance results are then normalized from 0 to 100 , and these values are used as energy performance estimation results for each building component. 
Table 9. Energy efficiency rating calculation table for heating energy consumption.

\begin{tabular}{|c|c|c|c|}
\hline \multirow[b]{2}{*}{ Design parameter } & \multirow[b]{2}{*}{ Building design component } & \multicolumn{2}{|c|}{ Heating energy } \\
\hline & & $\begin{array}{c}\text { Energy } \\
\text { efficiency } \\
\text { rating } \\
\end{array}$ & $\begin{array}{c}\text { Energy efficiency } \\
\text { performance } \\
\text { ratio (EEPR) } \\
\end{array}$ \\
\hline \multirow{8}{*}{ Orientation } & South & $1 \mathrm{st}$ & - \\
\hline & South West & 2nd & $+15.03 \%$ \\
\hline & South east & $3 \mathrm{rd}$ & $+16.34 \%$ \\
\hline & North & 4 th & $+30.05 \%$ \\
\hline & West & 5 th & $+33.70 \%$ \\
\hline & East & 6th & $+34.37 \%$ \\
\hline & North east & 7 th & $+36.30 \%$ \\
\hline & North west & 8 th & $+36.78 \%$ \\
\hline \multirow{7}{*}{ Air Exchange Rate } & $0.3 \mathrm{ac} / \mathrm{h}$ & $1 \mathrm{st}$ & - \\
\hline & $0.4 \mathrm{ac} / \mathrm{h}$ & 2nd & $+2.73 \%$ \\
\hline & $0.5 \mathrm{ac} / \mathrm{h}$ & $3 \mathrm{rd}$ & $+5.58 \%$ \\
\hline & $0.6 \mathrm{ac} / \mathrm{h}$ & 4 th & $+8.55 \%$ \\
\hline & $0.7 \mathrm{ac} / \mathrm{h}$ & 5 th & $+10.08 \%$ \\
\hline & $0.8 \mathrm{ac} / \mathrm{h}$ & 6th & $+13.03 \%$ \\
\hline & $0.9 \mathrm{ac} / \mathrm{h}$ & 7 th & $+15.78 \%$ \\
\hline \multirow{2}{*}{ Insulation location } & Outside insulation & $1 \mathrm{st}$ & - \\
\hline & Inside insulation & 2nd & $+6.71 \%$ \\
\hline \multirow{5}{*}{ Wall thickness (concrete) } & $300 \mathrm{~mm}$ & $1 \mathrm{st}$ & - \\
\hline & $250 \mathrm{~mm}$ & 2nd & $+0.1 \%$ \\
\hline & $200 \mathrm{~mm}$ & $3 \mathrm{rd}$ & $+0.25 \%$ \\
\hline & $150 \mathrm{~mm}$ & 4 th & $+0.33 \%$ \\
\hline & $100 \mathrm{~mm}$ & 5 th & $+0.41 \%$ \\
\hline \multirow{5}{*}{ Wall thickness (Insulation) } & $250 \mathrm{~mm}$ & $1 \mathrm{st}$ & - \\
\hline & $200 \mathrm{~mm}$ & 2nd & $+2.89 \%$ \\
\hline & $150 \mathrm{~mm}$ & $3 \mathrm{rd}$ & $+7.36 \%$ \\
\hline & $100 \mathrm{~mm}$ & 4 th & $+11.70 \%$ \\
\hline & $50 \mathrm{~mm}$ & 5 th & $+38.11 \%$ \\
\hline \multirow{6}{*}{ Window to Wall Ratio } & $100 \%$ & $1 \mathrm{st}$ & - \\
\hline & $90 \%$ & 2nd & $+3.17 \%$ \\
\hline & $80 \%$ & $3 \mathrm{rd}$ & $+7.07 \%$ \\
\hline & $70 \%$ & 4 th & $+11.73 \%$ \\
\hline & $60 \%$ & 5 th & $+16.81 \%$ \\
\hline & $50 \%$ & 6 th & $+22.91 \%$ \\
\hline \multirow{6}{*}{ Glass Type } & $\operatorname{Trp} \operatorname{LoE}(\mathrm{e} 5=1) 3 \mathrm{~mm} / 13 \mathrm{~mm} /$ Air & $1 \mathrm{st}$ & - \\
\hline & $\operatorname{Trp} \operatorname{Clr} 3 \mathrm{~mm} / 13 \mathrm{~mm} / \mathrm{Air}$ & 2nd & $+4.20 \%$ \\
\hline & $\operatorname{Dbl~LoE~}(\mathrm{e} 2=.1) \mathrm{Clr} 3 \mathrm{~mm} / 13 \mathrm{~mm} / \mathrm{Air}$ & $3 \mathrm{rd}$ & $+13.45 \%$ \\
\hline & Dbl Clr $3 \mathrm{~mm} / 13 \mathrm{~mm} / \mathrm{Air}$ & 4 th & $+16.64 \%$ \\
\hline & Sgl Loe $(\mathrm{e} 2=.4) \mathrm{Clr} 3 \mathrm{~mm}$ & 5 th & $+31.60 \%$ \\
\hline & $\mathrm{Sgl} \mathrm{Clr} 3 \mathrm{~mm}$ & 6th & $+58.62 \%$ \\
\hline
\end{tabular}


Table 9. Cont.

\begin{tabular}{|c|c|c|c|}
\hline \multirow[b]{2}{*}{ Design parameter } & \multirow[b]{2}{*}{ Building design component } & \multicolumn{2}{|c|}{ Heating energy } \\
\hline & & $\begin{array}{c}\text { Energy } \\
\text { efficiency } \\
\text { rating } \\
\end{array}$ & $\begin{array}{c}\text { Energy efficiency } \\
\text { performance } \\
\text { ratio (EEPR) }\end{array}$ \\
\hline \multirow{10}{*}{ Floor Area } & $45 \mathrm{~m}^{2}$ & $1 \mathrm{st}$ & - \\
\hline & $55 \mathrm{~m}^{2}$ & 2nd & $+7.39 \%$ \\
\hline & $65 \mathrm{~m}^{2}$ & $3 \mathrm{rd}$ & $+14.75 \%$ \\
\hline & $75 \mathrm{~m}^{2}$ & 4 th & $+23.12 \%$ \\
\hline & $85 \mathrm{~m}^{2}$ & 5 th & $+30.86 \%$ \\
\hline & $95 \mathrm{~m}^{2}$ & 6 th & $+38.96 \%$ \\
\hline & $105 \mathrm{~m}^{2}$ & 7 th & $+46.25 \%$ \\
\hline & $115 \mathrm{~m}^{2}$ & 8th & $+54.74 \%$ \\
\hline & $125 \mathrm{~m}^{2}$ & 9th & $+61.77 \%$ \\
\hline & $135 \mathrm{~m}^{2}$ & 10th & $+68.25 \%$ \\
\hline \multirow{5}{*}{ Proportion } & $2: 1$ & $1 \mathrm{st}$ & - \\
\hline & $1.75: 1$ & 2nd & $+0.96 \%$ \\
\hline & $1.5: 1$ & $3 r d$ & $+2.18 \%$ \\
\hline & $1.25: 1$ & 4th & $+7.48 \%$ \\
\hline & $1: 1$ & 5 th & $+16.14 \%$ \\
\hline \multirow{2}{*}{ Balcony type } & Closed & $1 \mathrm{st}$ & - \\
\hline & Room Extension & 2nd & $+3.11 \%$ \\
\hline \multirow{5}{*}{ Balcony depth } & $1000 \mathrm{~mm}$ & $1 \mathrm{st}$ & - \\
\hline & $1250 \mathrm{~mm}$ & 2nd & $+1.55 \%$ \\
\hline & $1500 \mathrm{~mm}$ & $3 \mathrm{rd}$ & $+3.10 \%$ \\
\hline & $1750 \mathrm{~mm}$ & 4 th & $+4.59 \%$ \\
\hline & $2000 \mathrm{~mm}$ & 5 th & $+6.10 \%$ \\
\hline \multirow{3}{*}{ Internal Wall Placement } & $\mathrm{H} 3$ & $1 \mathrm{st}$ & - \\
\hline & $\mathrm{H} 2$ & 2nd & $+3.61 \%$ \\
\hline & $\mathrm{H} 1$ & $3 \mathrm{rd}$ & $+10.4 \%$ \\
\hline \multirow{6}{*}{ Unit Location } & Middle Inside & $1 \mathrm{st}$ & - \\
\hline & Middle Outside & $2 \mathrm{nd}$ & $+14.84 \%$ \\
\hline & Top Inside & $3 r d$ & $+26.41 \%$ \\
\hline & Bottom Inside & 4 th & $+34.14 \%$ \\
\hline & Top Outside & 5 th & $+47.83 \%$ \\
\hline & Bottom Outside & 6 th & $+49.43 \%$ \\
\hline
\end{tabular}

\subsection{Validation}

To derive the impacts of input parameters on various simulation outputs as compared to the reference case, extensive perturbation studies were conducted. However, we needed to certify the proposed rating model based on a number of verification process simulations in order to validate the developed heuristic-rule-based energy evaluation model.

A total of 169 simulations were performed considering thirteen residential building design variables at thirteen levels. The first test sequence changed only one design parameter out of the thirteen parameters at a time. Then second test sequence randomly changed two parameters out of the thirteen 
parameters simultaneously for the combined test cases. Finally, thirteen sequence changes with every parameter were tested for thirteen levels. This extensive test was to determine whether an interrelation existed among the chosen design parameters. The correlation among the simulation outputs, which are annual building energy consumption, and the simulation results derived from building energy load assessment software and each of the outputs from the proposed model were examined using Equation (5) [37].

The correlation coefficient $\rho_{x, y}$ between two random variables $X$ and $Y$ with expected values of $\mu_{X}$ and $\mu_{Y}$ and the standard deviations $\sigma_{x}$ and $\sigma_{y}$ is defined as:

$$
\rho_{x, y}=\operatorname{corr}(X, Y)=\frac{\operatorname{cov}(X, Y)}{\sigma_{x} \sigma_{y}}=\frac{E\left[\left(X-\mu_{X}\right)\left(Y-\mu_{Y}\right)\right]}{\sigma_{x} \sigma_{y}}
$$

where $E$ is the expected value operator; cov represents the covariance; and corr is Pearson's correlation. There was less of a relationship (closer to uncorrelated) as the coefficient approached zero, whereas the closer the coefficient was to either -1 or 1 , the stronger the correlation between the variables.

Table 10 shows that the scatter plot of energy rating from the developed model linearly represent the relationship between the proposed model and the heating energy consumption derived from the simulation results. Case 1 is for the test performed by changing one design parameter at a time until each of thirteen different parameters is evaluated. Case 2 is for the test implemented by changing two design parameters at a time until all thirteen different parameters are evaluated. Likewise, Case 13 is for the test performed by changing every parameter at a time until each of thirteen different parameters is randomly evaluated.

Table 10. Correlation coefficient with estimated energy rating.

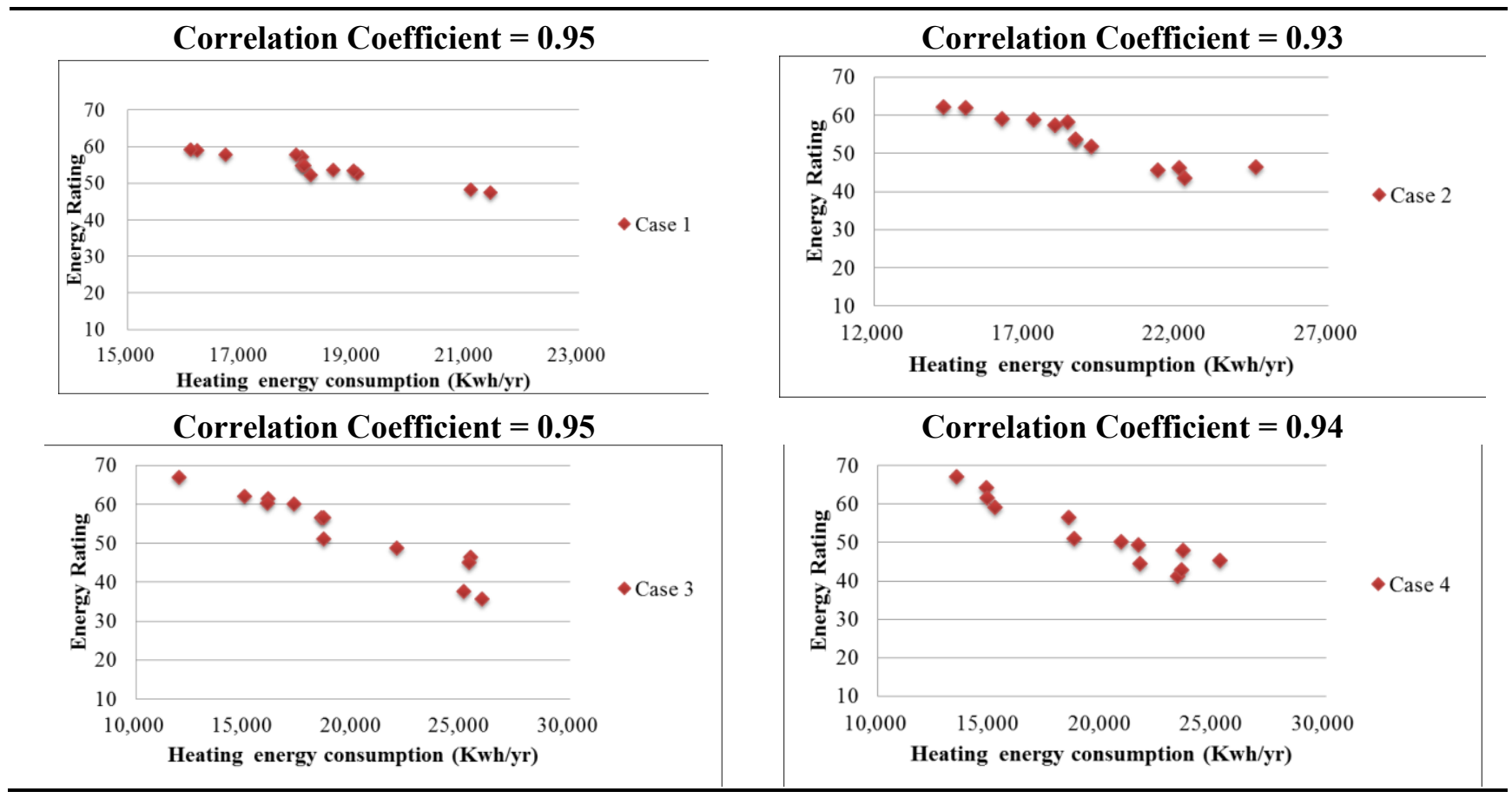


Table 10. Cont.

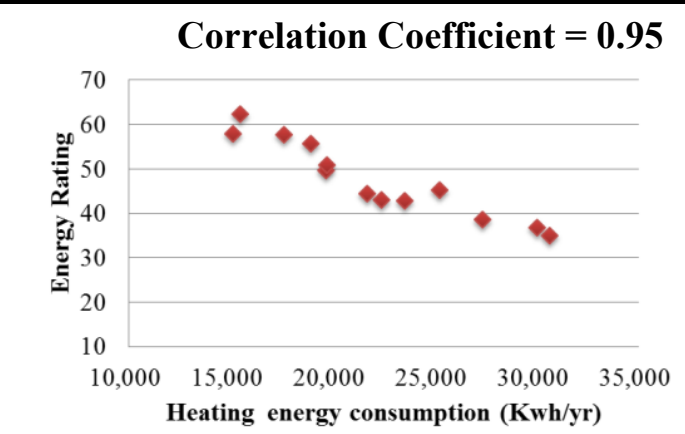

Correlation Coefficient $=\mathbf{0 . 9 5}$

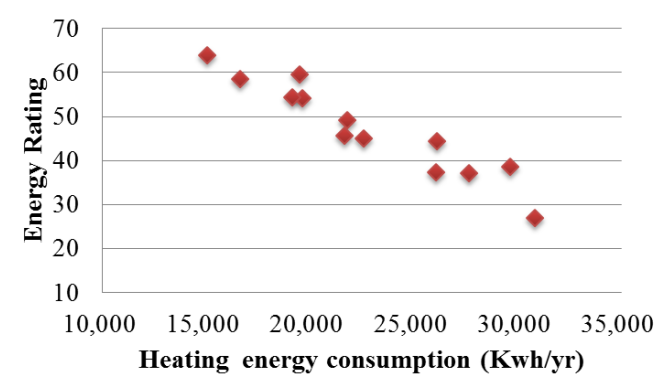

Correlation Coefficient $=\mathbf{0 . 9 3}$

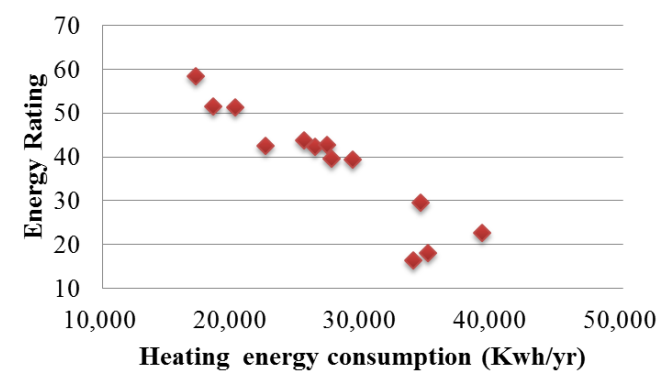

Correlation Coefficient $=\mathbf{0 . 9 6}$

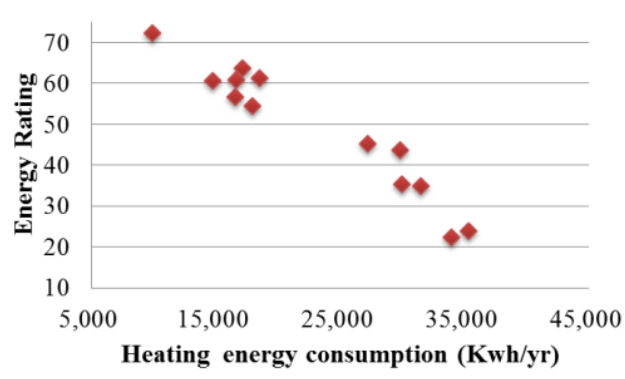

Correlation Coefficient $=\mathbf{0 . 9 5}$

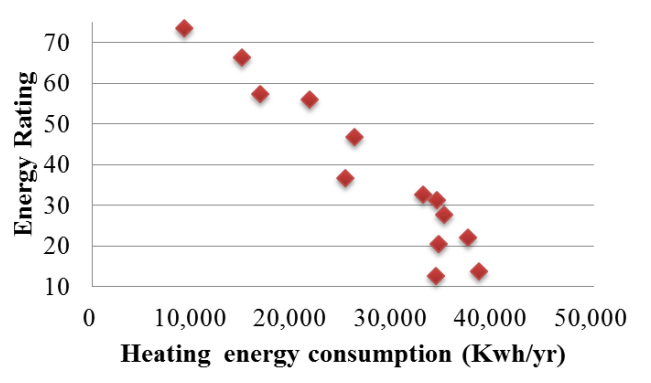

Correlation Coefficient $=0.93$
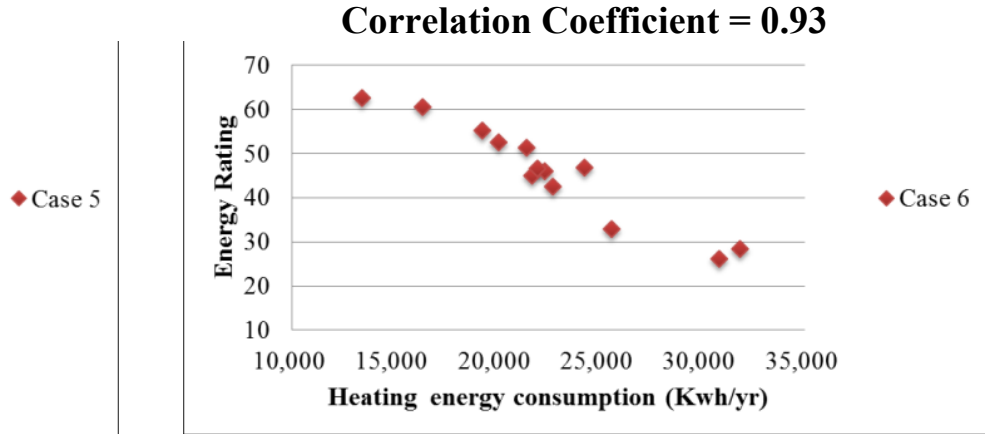

\section{Correlation Coefficient $=0.92$}

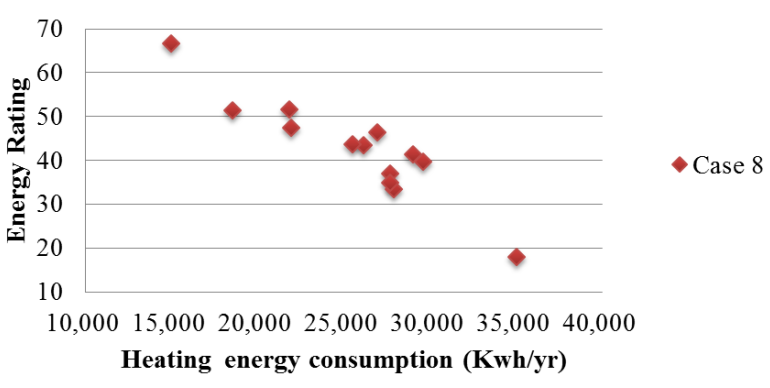

Correlation Coefficient $=\mathbf{0 . 9 5}$

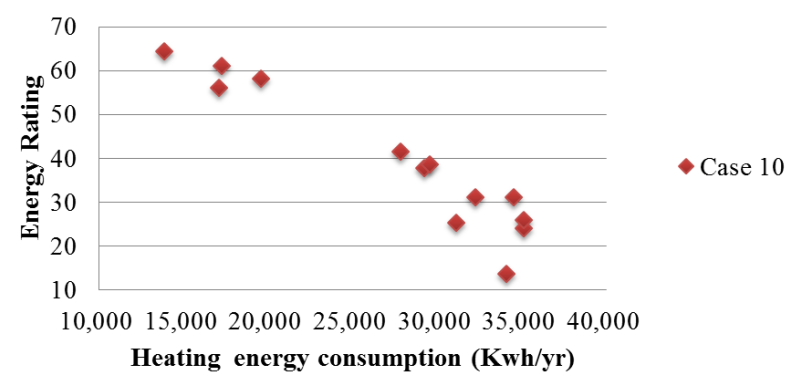

Correlation Coefficient $=0.92$

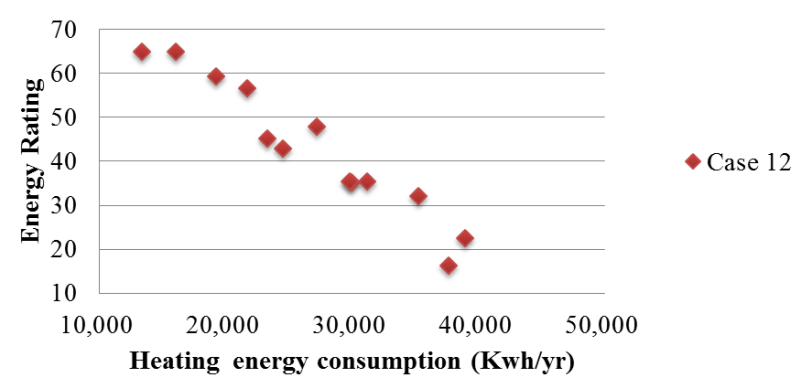


An extensive validation process was conducted under Korean apartment housing construction regulations and documentation guidelines to verify the energy performance model based on heuristic rules. Not only all the assumptions but also the non-linear effects of the same building design variables may reduce the performance of the model. However a high degree of non-linearity is not a significant issue in this research. The developed building energy estimation model based on heuristic rules could offer useful energy conscious design guidelines.

The initial design phase introduces an energy load profile, such as weighting factors for design categories and an Energy Efficiency Performance Ratio for the building design component, acquired by energy sensitive heuristic analysis. These factors should be considered in conjunction with the user's design preferences. Table 11 presents the heuristic rules that we offer as an effective guideline to selecting design parameters for energy-efficient design.

\subsection{Case Study}

We conducted a case study to test the energy performance model using building energy simulations. Table 12 shows the floor plan of a Korean apartment unit and the input parameters, and Table 13 presents eight energy-simulation-based case models designed using DesignBuilder. The simulation tests were conducted under the same conditions as the previous simulation.

First, the designed apartment unit model was evaluated using the EP model, whereupon the results showed a higher correlation coefficient with simulated heating energy consumption. Then a case study with apartment models based on the proposed heuristic rules was conducted and evaluated by a number of test sets.

Performing a case study based on the heuristic rules and the proposed EP model using several floor plans of existing apartment housings made it possible to ensure that the developed model can be used to measure the energy performance of a Korean apartment unit.

\subsection{Result Analysis}

Table 14 shows the correlation coefficient of the simulation results between heating energy consumption and the output of the EP model. It is obvious that the proposed model has a good correlation with the energy consumption. The estimation outcomes for a change in a single parameter have a high correlation with the simulated results. However, the correlation coefficient with the simulated output had a tendency to decrease when simultaneous changes to multiple variables were applied.

To validate the proposed heuristic rules, a total of 520 simulations were performed. Table 15 shows the building's energy simulation results with respect to heuristic rules. The results of the evaluation analysis of the several restrictive condition cases are described in Table 16.

Through the extensive systematic sensitivity analysis with a validation process, a heuristic rule-based passive design decision model for reducing heating energy consumption is summarized in Tables 11 and 16. 
Table 11. Heuristic Rule for minimizing heating energy consumption.

\section{Heuristic rule (HR)\#:Title}

HR1: Orientation

- An orientation with the balcony facing south consumes the lowest heating energy load.

- An orientation with the balcony facing northwest and northeast consume higher heating energy than that facing north due to solar radiation penetration, which enters the north side of the balcony.

- The air exchange rate is directly related to air tightness affecting energy consumption. The trade-off between the improved energy saving and indoor air quality needs to be considered.

- A higher air exchange rate consumes higher heating energy.

HR3: Insulation location

HR4: Wall concrete thickness

HR5: Wall insulation thickness

- Increased wall-concrete thickness reduces heating energy consumption.

- Increased wall-insulation thickness drastically reduces heating energy consumption.

- A larger window area is desirable to reduce heating energy load by the effect of solar heat gain.

HR6: Window to wall ratio

- The parameters that are greatly influenced by solar radiation are not relevant, especially in nort

HR7: Window type In this case, the window to wall ratio needs to be carefully considered for other insulations.

HR7: Window type

$-$

$-$

- An increasing proportion ratio consumes less heating energy load on the building due to the solar heat gain.

HR9: Plan proportion ratio

However, a higher plan proportion rate increases the heating energy load in the case of north, northeast, and northwest.

- The parameter that is significantly influenced by solar radiation is not relevant, especially in northern cases, and a lower plan proportion ratio is more relevant in the north side cases.

\begin{tabular}{|c|c|c|}
\hline HR10: Balcony type & - & A room extension balcony consumes more energy load than the closed balcony type due to an increased heating area and heat loss. \\
\hline HR11: Balcony depth & - & An increased balcony depth consumes a higher heating energy load than a decreased balcony depth due to the solar heat gain. \\
\hline HR12: Unit location & & $\begin{array}{l}\text { A unit with a middle floor location consumes the lowest heating energy and the bottom floor consumes the highest energy load. } \\
\text { A unit in an outside location consumes more heating energy than an inside unit. }\end{array}$ \\
\hline HR13: Internal wall placement & $\begin{array}{l}- \\
- \\
-\end{array}$ & $\begin{array}{l}\text { The heating energy performance decreases when the distance between the internal wall and the external balcony is increased due to solar } \\
\text { radiation and thermal loss. } \\
\text { With a room extension type of balcony, heating energy performance increases when the distance between the internal wall and the external } \\
\text { balcony is increased. } \\
\text { The parameter that is greatly influenced by solar radiation is nor relevant, especially in northern cases. }\end{array}$ \\
\hline
\end{tabular}


Table 12. The floor plan of a Korean apartment unit and input parameters.

\begin{tabular}{|c|c|c|c|c|c|c|c|c|}
\hline Category test set & Case A & Case B & Case C & Group D & Case $\mathbf{E}$ & Case $\mathbf{F}$ & Group G & Case H \\
\hline $\begin{array}{l}\text { Direction } \\
\text { (Base case) }\end{array}$ & \multicolumn{8}{|c|}{ From South to North (South) } \\
\hline $\begin{array}{l}\text { Air exchange rate } \\
\text { (Base case) }\end{array}$ & \multicolumn{8}{|c|}{ From $0.3 \mathrm{ac} / \mathrm{h}$ to $0.9 \mathrm{ac} / \mathrm{h}(0.7 \mathrm{ac} / \mathrm{h})$} \\
\hline $\begin{array}{c}\text { Insulation location } \\
\text { (Base case) }\end{array}$ & \multicolumn{8}{|c|}{ Inside/Outside insulation (Inside insulation) } \\
\hline $\begin{array}{l}\text { Wall thickness concrete } \\
\text { (Base case) }\end{array}$ & \multicolumn{8}{|c|}{ From $100 \mathrm{~mm}$ to $300 \mathrm{~mm}(200 \mathrm{~mm})$} \\
\hline $\begin{array}{l}\text { Wall thickness insulation } \\
\text { (Base case) }\end{array}$ & \multicolumn{8}{|c|}{ From $50 \mathrm{~mm}$ to $250 \mathrm{~mm}(150 \mathrm{~mm})$} \\
\hline $\begin{array}{l}\text { Window to wall ratio } \\
\text { (Base case) }\end{array}$ & \multicolumn{8}{|c|}{ From $50 \%$ to $100 \%(70 \%)$} \\
\hline $\begin{array}{l}\text { Window type } \\
\text { (Base case) }\end{array}$ & \multicolumn{8}{|c|}{6 different cases (Double Clear) } \\
\hline $\begin{array}{c}\text { Floor area size } \\
\text { (Base case) }\end{array}$ & \multicolumn{7}{|c|}{ From $65 \mathrm{~m}^{2}$ to $135 \mathrm{~m}^{2}$} & $\left(125 \mathrm{~m}^{2}\right)$ \\
\hline $\begin{array}{l}\text { Plan proportion } \\
\text { (Base case) }\end{array}$ & \multicolumn{8}{|c|}{5 cases $(1: 1,1.25: 1,1.5: 1,1.75: 1,2: 1)$} \\
\hline $\begin{array}{c}\text { Balcony type } \\
\text { (Base case) }\end{array}$ & \multicolumn{8}{|c|}{2 cases (Room Extension/Closed) } \\
\hline $\begin{array}{c}\text { Balcony depth } \\
\text { (Base case) }\end{array}$ & \multicolumn{8}{|c|}{5 cases (from $1000 \mathrm{~mm}$ to $2000 \mathrm{~mm}$ ) } \\
\hline $\begin{array}{c}\text { Internal wall placement } \\
\text { (Base case) }\end{array}$ & \multicolumn{8}{|c|}{3 cases $(\mathrm{H} 1 / \mathrm{H} 2 / \mathrm{H} 3)$} \\
\hline Base case floor plan & & & & : & $=1=$ & $=-7=$ & & \\
\hline
\end{tabular}


Table 13. Simulation models of a Korean apartment unit for case study.

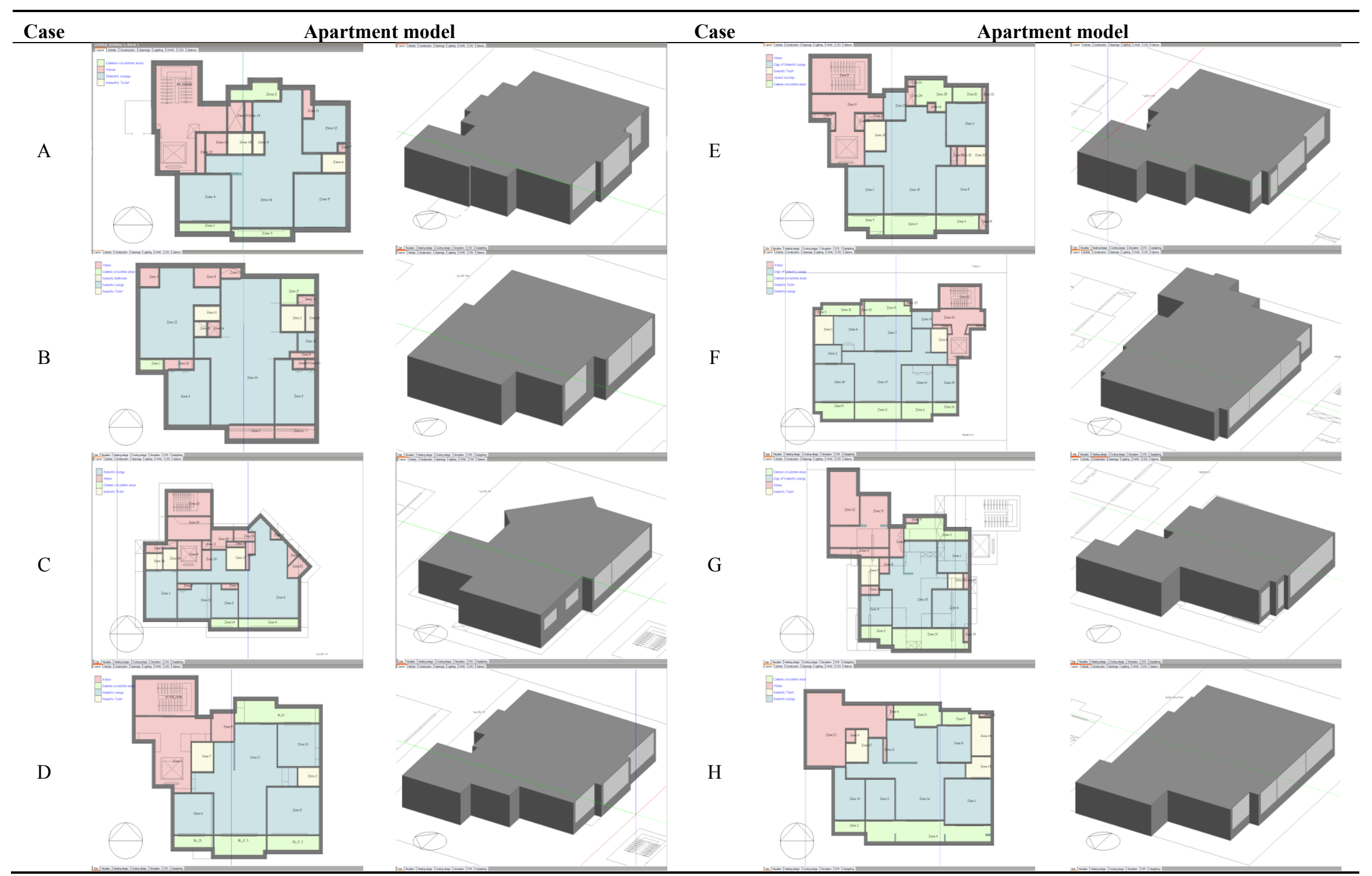

Every model is evaluated on the basis of bottom outside case. 
Table 14. Correlation coefficient result of EP model.

\begin{tabular}{|c|c|c|c|c|c|c|c|c|}
\hline \multirow{2}{*}{$\begin{array}{c}\text { NO. of } \\
\text { parameter change }\end{array}$} & \multicolumn{8}{|c|}{ Case } \\
\hline & $\mathbf{A}$ & B & $\mathbf{C}$ & D & $\mathbf{E}$ & $\mathbf{F}$ & $\mathbf{G}$ & $\mathbf{H}$ \\
\hline 1 & $(0.94)$ & $(0.96)$ & $(0.97)$ & $(0.95)$ & $(0.96)$ & $(0.93)$ & $(0.94)$ & $(0.92)$ \\
\hline 2 & $(0.96)$ & $(0.94)$ & $(0.94)$ & $(0.96)$ & $(0.97)$ & $(0.90)$ & $(0.96)$ & $(0.92)$ \\
\hline 3 & $(0.97)$ & $(0.95)$ & $(0.93)$ & $(0.90)$ & $(0.91)$ & $(0.88)$ & $(0.95)$ & $(0.88)$ \\
\hline 4 & $(0.91)$ & $(0.91)$ & $(0.91)$ & $(0.95)$ & $(0.93)$ & $(0.88)$ & $(0.90)$ & $(0.91)$ \\
\hline 5 & $(0.92)$ & $(0.92)$ & $(0.92)$ & $(0.93)$ & $(0.92)$ & $(0.90)$ & $(0.93)$ & $(0.90)$ \\
\hline 6 & $(0.94)$ & $(0.96)$ & $(0.90)$ & $(0.92)$ & $(0.91)$ & $(0.88)$ & $(0.94)$ & $(0.89)$ \\
\hline 7 & $(0.94)$ & $(0.95)$ & $(0.91)$ & $(0.94)$ & $(0.93)$ & $(0.90)$ & $(0.96)$ & $(0.90)$ \\
\hline 8 & $(0.93)$ & $(0.92)$ & $(0.92)$ & $(0.90)$ & $(0.91)$ & $(0.84)$ & $(0.93)$ & $(0.86)$ \\
\hline 9 & $(0.92)$ & $(0.91)$ & $(0.91)$ & $(0.91)$ & $(0.93)$ & $(0.89)$ & $(0.94)$ & $(0.84)$ \\
\hline 10 & $(0.89)$ & $(0.93)$ & $(0.90)$ & $(0.90)$ & $(0.90)$ & $(0.80)$ & $(0.90)$ & $(0.86)$ \\
\hline 11 & $(0.91)$ & $(0.92)$ & $(0.95)$ & $(0.87)$ & $(0.89)$ & $(0.87)$ & $(0.89)$ & $(0.82)$ \\
\hline 12 & $(0.90)$ & $(0.90)$ & $(0.88)$ & $(0.89)$ & $(0.89)$ & $(0.82)$ & $(0.88)$ & $(0.81)$ \\
\hline 13 & $(0.91)$ & $(0.91)$ & $(0.89)$ & $(0.88)$ & $(0.91)$ & $(0.83)$ & $(0.91)$ & $(0.82)$ \\
\hline
\end{tabular}

Every test is conducted by 13 test sets. 
Table 15. The evaluation result for heuristic rules.

\begin{tabular}{|c|c|c|c|c|c|c|c|c|c|}
\hline Heuristic rules & Case & NO. test & $\mathbf{P}$ & $\mathbf{F}$ & Heuristic rules & Case & NO. Test & $\mathbf{P}$ & $\mathbf{F}$ \\
\hline \multirow{8}{*}{ Heuristic rule 01} & Case A & 5 & 5 & - & \multirow{8}{*}{ Heuristic rule 08} & Case A & 5 & 5 & - \\
\hline & Case B & 5 & 5 & - & & Case B & 5 & 5 & - \\
\hline & Case C & 5 & 5 & - & & Case $\mathrm{C}$ & 5 & 5 & - \\
\hline & Case D & 5 & 5 & - & & Case D & 5 & 5 & - \\
\hline & Case E & 5 & 5 & - & & Case E & 5 & 5 & - \\
\hline & Case F & 5 & 5 & - & & Case F & 5 & 5 & - \\
\hline & Case G & 5 & 5 & - & & Case G & 5 & 5 & - \\
\hline & Case $\mathrm{H}$ & 5 & 5 & - & & Case $\mathrm{H}$ & 5 & 5 & - \\
\hline \multirow{8}{*}{ Heuristic rule 02} & Case A & 5 & 5 & - & \multirow{8}{*}{ Heuristic rule 09} & Case A & 5 & 4 & 1 \\
\hline & Case B & 5 & 5 & - & & Case B & 5 & 4 & 1 \\
\hline & Case C & 5 & 5 & - & & Case C & 5 & 3 & 2 \\
\hline & Case D & 5 & 5 & - & & Case D & 5 & 4 & 1 \\
\hline & Case E & 5 & 5 & - & & Case E & 5 & 4 & 1 \\
\hline & Case F & 5 & 5 & - & & Case F & 5 & 4 & 1 \\
\hline & Case G & 5 & 5 & - & & Case G & 5 & 4 & 1 \\
\hline & Case $\mathrm{H}$ & 5 & 5 & - & & Case $\mathrm{H}$ & 5 & 4 & 1 \\
\hline \multirow{8}{*}{ Heuristic rule 03} & Case A & 5 & 5 & - & \multirow{8}{*}{ Heuristic rule 10} & Case A & 5 & 5 & - \\
\hline & Case B & 5 & 5 & - & & Case B & 5 & 5 & - \\
\hline & Case C & 5 & 5 & - & & Case C & 5 & 5 & - \\
\hline & Case D & 5 & 5 & - & & Case D & 5 & 5 & - \\
\hline & Case E & 5 & 5 & - & & Case E & 5 & 5 & - \\
\hline & Case F & 5 & 5 & - & & Case F & 5 & 4 & 1 \\
\hline & Case G & 5 & 5 & - & & Case G & 5 & 5 & - \\
\hline & Case $\mathrm{H}$ & 5 & 5 & - & & Case $\mathrm{H}$ & 5 & 5 & - \\
\hline \multirow{8}{*}{ Heuristic rule 04} & Case A & 5 & 5 & - & \multirow{8}{*}{ Heuristic rule 11} & Case A & 5 & 5 & - \\
\hline & Case B & 5 & 5 & - & & Case B & 5 & 5 & - \\
\hline & Case C & 5 & 5 & - & & Case C & 5 & 5 & - \\
\hline & Case D & 5 & 5 & - & & Case D & 5 & 5 & - \\
\hline & Case E & 5 & 5 & - & & Case E & 5 & 5 & - \\
\hline & Case F & 5 & 5 & - & & Case F & 5 & 5 & - \\
\hline & Case G & 5 & 5 & - & & Case G & 5 & 5 & - \\
\hline & Case $\mathrm{H}$ & 5 & 5 & - & & Case $\mathrm{H}$ & 5 & 5 & - \\
\hline \multirow{8}{*}{ Heuristic rule 05} & Case A & 5 & 5 & - & \multirow{8}{*}{ Heuristic rule 12} & Case A & 5 & 5 & - \\
\hline & Case B & 5 & 5 & - & & Case B & 5 & 5 & - \\
\hline & Case C & 5 & 5 & - & & Case C & 5 & 5 & - \\
\hline & Case D & 5 & 5 & - & & Case D & 5 & 5 & - \\
\hline & Case E & 5 & 5 & - & & Case E & 5 & 5 & - \\
\hline & Case F & 5 & 5 & - & & Case F & 5 & 5 & - \\
\hline & Case G & 5 & 5 & - & & Case G & 5 & 5 & - \\
\hline & Case $\mathrm{H}$ & 5 & 5 & - & & Case $\mathrm{H}$ & 5 & 5 & - \\
\hline
\end{tabular}


Table 15. Cont.

\begin{tabular}{|c|c|c|c|c|c|c|c|c|c|}
\hline Heuristic rules & Case & No. Test & $\mathbf{P}$ & $\mathbf{F}$ & Heuristic rules & Case & No. Test & $\mathbf{P}$ & $\mathbf{F}$ \\
\hline \multirow{8}{*}{ Heuristic rule 06} & Case A & 5 & 4 & 1 & \multirow{8}{*}{ Heuristic rule 13} & Case A & 5 & 5 & - \\
\hline & Case B & 5 & 4 & 1 & & Case B & 5 & 5 & - \\
\hline & Case C & 5 & 3 & 2 & & Case C & 5 & 3 & 2 \\
\hline & Case D & 5 & 4 & 1 & & Case D & 5 & 5 & - \\
\hline & Case E & 5 & 4 & 1 & & Case E & 5 & 4 & 1 \\
\hline & Case F & 5 & 4 & 1 & & Case F & 5 & 5 & - \\
\hline & Case G & 5 & 4 & 1 & & Case G & 5 & 5 & - \\
\hline & Case $\mathrm{H}$ & 5 & 4 & 1 & & Case H & 5 & 4 & 1 \\
\hline \multirow{8}{*}{ Heuristic rule 07} & Case A & 5 & 5 & - & & \multirow{8}{*}{-} & & & \\
\hline & Case B & 5 & 5 & - & & & & & \\
\hline & Case C & 5 & 5 & - & & & & & \\
\hline & Case D & 5 & 5 & - & & & & & \\
\hline & Case E & 5 & 5 & - & & & & & \\
\hline & Case F & 5 & 5 & - & & & & & \\
\hline & Case G & 5 & 5 & - & & & & & \\
\hline & Case $\mathrm{H}$ & 5 & 5 & - & & & & & \\
\hline
\end{tabular}

Table 16. Energy efficiency weight and restrictive conditions for design decision model.

\begin{tabular}{|c|c|}
\hline Concerns & Description \\
\hline $\begin{array}{l}\text { Energy efficient } \\
\text { weight priority for } \\
\text { design parameters }\end{array}$ & $\begin{array}{ll}\text { - } & \text { Building's orientation should be firstly considered in design process. } \\
\text { - } & \text { Following sequence presents design priority for parameter selection } \\
\text { considering energy influence factor: } \\
\text { - } \quad \text { Heating energy load } \\
\text { 1. } \quad \text { Orientation } \\
\text { 2. } \quad \text { Unit Location } \\
\text { 3. } \quad \text { Glass Type } \\
\text { 4. } \quad \text { Floor Area } \\
\text { 5. } \quad \text { Wall thickness(Insulation) } \\
6 . \quad \text { Window to Wall Ratio } \\
\text { 7. } \quad \text { Air Exchange Rate } \\
\text { 8. } \quad \text { Plan Proportion } \\
\text { 9. } \quad \text { Internal Wall Placement } \\
\text { 10. } \quad \text { Insulation location } \\
\text { 11. } \quad \text { Balcony depth } \\
\text { 12. } \quad \text { Balcony type } \\
13 . \quad \text { Wall thickness (concrete) }\end{array}$ \\
\hline $\begin{array}{l}\text { Restrictive } \\
\text { condition cases }\end{array}$ & $\begin{array}{l}\text { - Parameters seriously affected by solar radiation, such as window to wall ratio, } \\
\text { plan proportion, and internal wall placement should be carefully selected } \\
\text { especially in north, northeast and northwest orientation. }\end{array}$ \\
\hline
\end{tabular}




\section{Summary and Conclusions}

Buildings are responsible for a large portion of the total energy consumption of most countries. To reduce building energy use, it is necessary to optimize building design for energy efficiency at the early design phase so as to have the greatest impact on a building's thermal performance. Decisions made in the early design process, such as selection of a building's architectural components, form, and orientation, can remarkably decrease or increase a building's energy performance. Therefore, it is necessary to provide designers or architects with design decision support models to assist them with energy efficient design decisions in the early design phase.

This study presents a heuristic rule-based passive design decision model for reducing heating energy efficiency of the design choices of architects and engineers. The perturbation studies are based on sensitivity analysis to identify the thermal influence of input design parameters on various simulation outputs, as compared to a base case situation.

The energy sensitive weight factors are also retrieved by an extensive sensitivity study using building energy simulations. The results of the energy sensitivity study that were summarized in a set of heuristic rules for evaluating architectural features were estimated through case studies of Korean apartment floor plans.

Moreover, various constraints and mixed design conditions for each heuristic rule are also verified through a number of simulation test sets under the typical Korean residential environments. With access to such energy sensitive heuristic rules, architects or designers can decide on the best design alternative for meeting the objective of minimum heating energy consumption.

This study could play a crucial role in providing valuable guidelines for developing energy-efficient residential housing in Korea by helping architects consider appropriate design schemes and by offering a ready reference to generalized test cases for both architects and engineers that allow them to zero in on a set of effective design solutions.

Building's Life Cycle Cost Analysis (LCCA) is not considered in this study. Therefore, further studies are required to derive an energy and cost conscious design decision model to maximize energy savings and minimize costs by adopting a practical set of design variables that consider energy sensitive design parameters. To that end, further studies should also be conducted on the exploration of heuristic rules for validating sustainable apartment design in Korea based on energy sensitivity and LCCA, which promises to be an appropriate support solution for green apartment housing design decisions in the early design phase.

A green-home-design decision support model should allow architects, engineers and users to evaluate building energy load for various combinations of architectural design features without requiring specific knowledge on building energy processes or green home design and construction regulations. Such an approach requires the development of a sustainable housing design decision support system supported by the cohesive consideration of energy and cost reduction which both facilitate energy sensitive architectural design approaches and estimates the economic effect of design solutions.

Although we mainly focus on Korean apartment building case in this study, we believe the methodology developed here in this research could easily be generalized to establish equally energy efficient design decision support models for different residential types in other regions or countries. 


\section{Acknowledgments}

This work was supported by grant NO. EEWS-2014-N01140044 from EEWS Research Project of the KAIST EEWS Research Center. (EEWS: Energy, Environment, Water and Sustainability).

\section{Author Contributions}

All authors contributed to this work. All authors designed the heuristic rules, performed simulations, discussed the outcomes and derived the analysis results in preparing the manuscript for publication.

\section{Conflicts of Interest}

The authors declare no conflict of interest.

\section{References}

1. Huovila, P. Buildings and Climate Change: Status, Challenges, and Opportunities; UNEP/Earthprint: Hertfordshire, UK, 2007.

2. Suh, D.; Chang, S. An energy and water resource demand estimation model for multi-family housing complexes in Korea. Energies 2012, 5, 4497-4516.

3. Ministry of Knowledge Economy, Energy Consumption Survey. Available online: http://www.keei.re.kr/web_keei/d_results.nsf/0/0741354B0AFE8387492575EC00164F78/\$file/ ESV08.pdf (accessed on 23 October 2014).

4. Kim, S.; Yang, I.; Yeo, M.; Kim, K. Development of a housing performance evaluation model for multi-family residential buildings. Build. Environ. 2005, 40, 1103-1116.

5. Hong, T.; Koo, C.; Park, S. A decision support model for improving a multi-family housing complex based on $\mathrm{CO}_{2}$ emission from gas energy consumption. Build. Environ. 2012, 52, 142-151.

6. Jeong, Y.-S.; Lee, S.-E.; Huh, J.-H. Estimation of $\mathrm{CO}_{2}$ emission of apartment buildings due to major construction materials in the Republic of Korea. Energy Build. 2012, 49, 437-442.

7. Choi, D.-H.; Hyun, D.-S.; Park, H.-S. A study on energy consumption of apartment buildings in Cheju. J. Arch. Inst. Korea 1999, 15, 181-188.

8. Chang, S.; Honnekeri, A.; Suh, D. Exploration of heuristic rules in mass housing design space for minimised energy consumption and $\mathrm{CO}_{2}$ emission. In Proceedings of the 13th Conference International Building Performance Simulation Association (IBPSA), Chambéry, France, 26-28 August 2013.

9. Kim, H.; Suh, D.; Chang, S. Exploration of heuristic rules for green home design decision support system. In Proceedings of the 20129th International Conference \& Expo on Emerging Technologies for a Smarter World, Incheon, Korea, 5-6 November 2012; pp. 1-6.

10. Lam, J.C.; Hui, S.C.M. Sensitivity analysis of energy performance of office buildings. Build. Environ. 1996, 31, 27-39.

11. Tavares, P.F.A.F.; Martins, A.M.O.G. Energy efficient building design using sensitivity analysis - A case study. Energy Build. 2007, 39, 23-31.

12. Westphal, F.S.; Lamberts, R. building simulation calibration using sensitivity analysis. In Proceedings of the Building Simulation 2005, International Building Performance Simulation Association (IBPSA) Conference, Montréal, QC, Canada, 15-18 August 2005. 
13. Bouchlaghem, N.M.; Letherman, K.M. Numerical optimization applied to the thermal design of buildings. Build. Environ. 1990, 25, 117-124.

14. Hong, W.; Bae, H.; Kim, S.; Choi, M. A study on the energy consumption by the life style of resident in apartment houses. Korean J. Arch. Inst. Korea 1998, 14, 193-200.

15. Choi, I.Y.; Cho, S.H.; Kim, J.T. Energy consumption characteristics of high-rise apartment buildings according to building shape and mixed use development. Energy Build. 2012, 46, 123-131.

16. Kim, J.-G.; Chun, J.-S.; Lee, B.-H. Comparative study on the city gas consumption characteristics of flat-type apartment and tower-type apartment. Resid. Environ. Inst. Korea 2009, 7, 55-65.

17. Lee, B.; Lee, J.; Je, H.; Kang, D. A study on the characteristic of energy consumption in the super high-rise mixed-use housing. J. Korean Inst. Ecol. Arch. Environ. 2010, 10, 63-70.

18. Choi, W.-K.; Kim, H.-J.; Suh, S.-J. A study on the analysis of energy consumption patterns according to the building shapes with the same volume. J. Korean Solar Energy Soc. 2007, 27, $103-109$.

19. Lee, C.-G.; Suh, S.-J. A Study on the greenhouse gas intensity of building groups and regional in Korea. J. Korean Solar Energy Soc. 2012, 32, 162-169.

20. Choi, W.-K.; Kim, H.-J.; Lee, H.-G.; Suh, S.-J. Theoretical study on the patterns of temperature variation and thermal load according to each household heating and cooling in apartment. Korean J. Arch. Inst. Korea 2007, 23, 279-288.

21. Yoon, S.-H.; Jang, H.-K.; Kim, Y.-T. Analysis on the characteristics of thermal load classified by the household location in apartment house. Korean J. Arch. Inst. Korea 2009, 10, 289-296. (In Korean)

22. Kim, J.-G.; Lee, B.-H. A study on the investigation of the amount of city gas use for the location of a major apartment building and households. Korean J. Arch. Inst. Korea 2005, 21, 217-226.

23. Yoon, J.-H.; Kim, B.-S. Energy performance evaluation of zero energy technologies for zero energy multi-house. J. Korean Solar Energy Soc. 2007, 27, 161-167.

24. Choi, M.-S.; Chang, S.-J. Comparative analysis on the heating and cooling loads associated with U-value, SHGC and orientation of the windows in different regions. J. Korean Inst. Ecol. Arch. Environ. 2013, 4, 123-130.

25. Leadership in Energy and Environmental Design (LEED). Available online: http://www.usgbc.org/leed (accessed on 23 October 2014).

26. Comprehensive Assessment System for Building Environment Efficiency. Available online: http://www.ibec.or.jp/CASBEE/english/ (accessed on 23 October 2014).

27. Green Building Certification Criteria. Available online: http://koreagbc.org/ (accessed on 23 October 2014).

28. Passive House Institute, Certified Passive House. Available online: http://www.passiv.de/ en/03_certification/02_certification_buildings/02_certification_buildings.htm (accessed on 23 October 2014).

29. Lam, J.C.; Wan, K.K.; Yang, L. Sensitivity analysis and energy conservation measures implications. Energy Convers. Manag. 2008, 49, 3170-3177.

30. Spitler, J.D.; Fisher, D.E.; Zietlow, D.C. A primer on the use of influence coefficients in building simulation. In Proceedings of the Building Simulation 1989, International Building Performance Simulation Association (IBPSA) Conference, Vancouver, BC, Canada, 23-24 June 1989. 
31. Baek, H.-S.; Choi, S.-H.; Choi, D.-S.; Joo, J.-Y. Planning Design Guidelines for LH Unit Plan; Land and Housing Institute: Daejeon, Korea, 2012. (In Korean)

32. A Guideline of Window Construction for Building Energy Efficiency; Ministry of Land Transport and Maritime Affairs: Seoul, Korea, 2012.

33. A Building Insulation Standards; Ministry of Land Transport and Maritime Affairs: Seoul, Korea, 2011.

34. DesignBuilder. Available online: http://www.designbuilder.co.uk/content/view/29/44 (accessed on 23 October 2014).

35. U.S. Department of Energy (DOE). Available online: http://apps1.eere.energy.gov/buildings/ tools_directory/software.cfm/ID=486/pagename=alpha_list (accessed on 23 October 2014).

36. Chartered Institute of Building Services Engineers. Environmental Factors Affecting Office Worker Performance: A Review of Evidence; Chartered Institute of Building Services Engineers: London, UK, 1999.

37. Benesty, J.; Chen, J.; Huang, Y.; Cohen, I. Pearson correlation coefficient. In Noise Reduction in Speech Processing; Springer: Berlin/Heidelberg, Germany, 2009; Volume 2, pp. 1-4.

(C) 2014 by the authors; licensee MDPI, Basel, Switzerland. This article is an open access article distributed under the terms and conditions of the Creative Commons Attribution license (http://creativecommons.org/licenses/by/4.0/). 